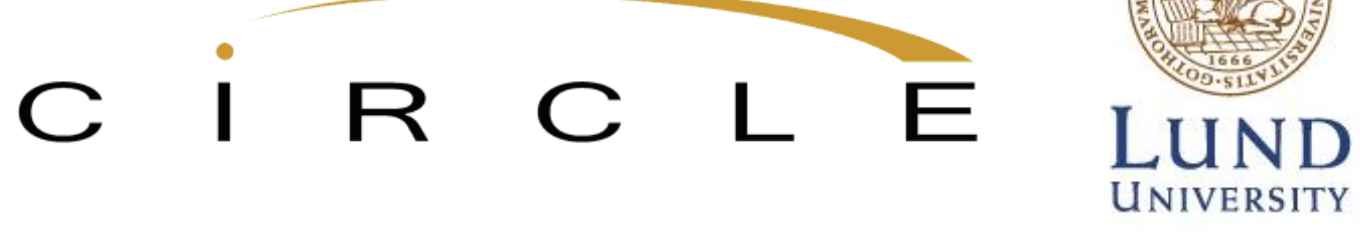

Paper no. 2014/04

\title{
Local Competitiveness Fostered through Local Institutions for Entrepreneurship
}

\author{
Martin Andersson (martin.andersson@circle.lu.se) \\ CIRCLE, Lund University and the Department of Industrial Economics and \\ Management, Blekinge Institute of Technology \\ Magnus Henrekson (magnus.henrekson@ifn.se) \\ Research Institute of Industrial Economics (IFN)
}

This is a post-print version of a paper that has been accepted for publication in Oxford Handbook of Local Competitiveness, edited by David B. Audretsch, Albert N. Link and Mary Walshok, and to be published by Oxford University Press. Citations should refer to the final publications.

This version: May 2014

Centre for Innovation, Research and Competence in the Learning Economy (CIRCLE)

Lund University

P.O. Box 117, Sölvegatan 16, S-221 00 Lund, SWEDEN

http://www.circle.lu.se/publications 


\section{WP 2014/04 \\ Local Competiveness Fostered through Local Institutions for Entrepreneurship \\ Martin Andersson \\ Magnus Henrekson}

\section{Abstract}

We review and assess the role local institutional framework conditions play in fostering local entrepreneurship. The basic premise is that entrepreneurship is a central driver of economic renewal and change, and that institutions affect both the supply and direction of entrepreneurship. While local institutions always develop and operate against the backdrop of national institutional frameworks, in particular in non-federal states, our review shows that there is plenty of room for local initiatives and policies to influence the entrepreneurial climate locally. This pertains to both formal (e.g., taxes, regulations and stringency of enforcement) and informal (e.g., attitudes and social legitimacy) institutions. We further argue that the local institutional environment is essential in any local policy aimed to foster productive (high-impact) entrepreneurship. Favorable local institutions not only increase the odds that a region develops or manage to attract entrepreneurial incumbents, but also the odds that a region reaps the full potential of hosting entrepreneurial and knowledge-intensive activities.

JEL codes: D22; H70; L26; M13; O43; R38

Keywords: Business climate; Entrepreneurship; Institutions; Job creation; Local policies; Startups; Regulations; Entrepreneurship culture; High-impact entrepreneurs

Disclaimer: All the opinions expressed in this paper are the responsibility of the individual author or authors and do not necessarily represent the views of other CIRCLE researchers. 


\title{
Local Competitiveness Fostered through Local Institutions for Entrepreneurship ${ }^{*}$
}

\author{
Martin Andersson ${ }^{1}$ and Magnus Henrekson ${ }^{2}$
}

This version: April 28, 2014

\begin{abstract}
We review and assess the role local institutional framework conditions play in fostering local entrepreneurship. The basic premise is that entrepreneurship is a central driver of economic renewal and change, and that institutions affect both the supply and direction of entrepreneurship. While local institutions always develop and operate against the backdrop of national institutional frameworks, in particular in non-federal states, our review shows that there is plenty of room for local initiatives and policies to influence the entrepreneurial climate locally. This pertains to both formal (e.g., taxes, regulations and stringency of enforcement) and informal (e.g., attitudes and social legitimacy) institutions. We further argue that the local institutional environment is essential in any local policy aimed to foster productive (high-impact) entrepreneurship. Favorable local institutions not only increase the odds that a region develops or manage to attract entrepreneurial incumbents, but also the odds that a region reaps the full potential of hosting entrepreneurial and knowledge-intensive activities.
\end{abstract}

Keywords: Business climate; Entrepreneurship; Institutions; Job creation; Local policies; Startups; Regulations; Entrepreneurship culture; High-impact entrepreneurs

JEL Codes: D22; H70; L26; M13; O43; R38.

${ }^{1}$ CIRCLE, Lund University and the Department $\quad{ }^{2}$ Research Institute of Industrial

of Industrial Economics and Management, Economics (IFN)

Blekinge Institute of Technology

P.O. Box 117

P.O. Box 55665

SE-221 00 Lund, Sweden

SE-102 15 Stockholm, Sweden

martin.andersson@circle.lu.se magnus.henrekson@ifn.se

\footnotetext{
${ }^{*}$ This is a contribution to the Oxford Handbook of Local Competitiveness, edited by David B. Audretsch, Albert N. Link and Mary Walshok, and to be published by Oxford University Press. We are grateful for useful comments and suggestions from Al link and two anonymous referees. We gratefully acknowledge financial support from the Jan Wallander and Tom Hedelius Research Foundation and from a grant from the Swedish Research Council for Environment, Agricultural Sciences and Spatial Planning (FORMAS), Dnr 2011-80. Martin Andersson further acknowledges support from the Swedish Research Council (Linnaeus Grant No. 349200680) and the Swedish Governmental Agency for Innovation Systems (Grant agreement 2010-07370).
} 


\section{Introduction}

Without implicating an analogy with the competitiveness of a firm (cf. Krugman 1994), we can think of local competitiveness as the capacity of a local economy to continuously renew its economic base. New technology, innovations, globalization and changes in the organization of production imply gradual shifts in the nature of competition and in the geography of production (Dicken 2003). Cities and regions that do not respond and adapt to such changing conditions, for example by diversifying and entering new industries, will decline as the industries or activities upon which the local economy was historically built fall behind in the global competition. A prime example is the U.S. city of Detroit. It went from being one of the most prosperous cities in the country in the 1950s, to losing a significant portion of its population and jobs and to ultimately file for bankruptcy in July 2013. One of the main explanations for this development centers around the city's historical reliance on a single industry, car manufacturing, and its failure to adapt and diversify into new industries. Detroit accordingly declined when its local automotive industry weakened and faced trouble handling fiercer competition from abroad. ${ }^{1}$

A key issue then concerns the mechanisms by which a local economy adapts and reinvents itself, and what factors that influence those mechanisms. The point of departure of this chapter is that entrepreneurship is a central driver of renewal. After all, the very definition of entrepreneurship emphasizes that it is about individuals and organizations-be they new, old, large or small-that actively contribute to renewal and change in an economy (Hébert and Link 2006a). Joseph Schumpeter (1934) indeed attributed the entrepreneur a critical role in processes of industrial evolution and economic dynamics. The entrepreneur, Schumpeter claimed, is particularly important in inducing structural change because she challenges existing economic structures through innovations that disturb current market equilibria. A large empirical research literature has also shown that small entrepreneurial firms and startups are important in bringing in new technology and innovations (Baumol 2002; Audretsch 2002; Schneider and Veugelers 2010), in influencing innovation and productivity of incumbents (Aghion et al. 2004, 2009) and in stimulating overall productivity and employment growth (Fritsch and Mueller 2004; Fritsch and Noseleit 2013; Andersson, Braunerhjelm and Thulin 2012). It follows that "local competitiveness", as defined above, hinges to a large extent on the environment for entrepreneurship.

The central message in this chapter is that a crucial constituent of the environment for entrepreneurship is the institutional setup, because it influences both the supply and direction of entrepreneurial activity.

\footnotetext{
${ }^{1}$ See for instance the article "Anatomy of Detroit's Decline" published on December 8, 2013 in the New York Times (http://www.nytimes.com/interactive/2013/08/17/us/detroit-decline.html? r=0)
} 
Following North (1990), institutions are understood as "the rules of the game" that determine the incentives for individual effort and for investments in capital (physical and human) and in technology. Institutions can either be formal (laws, regulations, constitutions) or informal (customs, traditions, norms). The role both types of institutions play for entrepreneurship is also recognized by Schumpeter (1934). In discussing what he referred to as the reaction of the "social environment" to entrepreneurship he stated (pp. 86-87):

This reaction may manifest itself first of all in the existence of legal or political impediments. But neglecting this, any deviating conduct by a member of a social group is condemned, though in greatly varying degrees according as the social group is used to such conduct or not.

It may seem odd to emphasize the sub-national scale in the context of institutions. Taxes, labor market regulations, property rights and other types of institutions are generally determined the national level. Such institutions therefore show no or very small variations across sub-national regions-at least in nonfederal states-which means that they cannot be an important component of the local environment for entrepreneurship. Their influence on entrepreneurship is accordingly often analyzed in cross-country studies (e.g., Braunerhjelm and Eklund 2014, Djankov et al. 2010 and Nicoletti and Scarpetta 2003). We argue indeed that local institutions for entrepreneurship always develop and emerge against the backdrop of a national institutional context. For instance, when Toyota decided to begin production in Europe, they located their first production plant at Deeside in North Wales. However, before settling on Deeside, Toyota identified the UK as offering the most favorable national framework conditions for their production facilities.

The local institutional context still matters for at least three reasons. First, there are local variations in the formal regulatory business framework. Even in non-federal states, the formal regulations concerning, for example, licenses to open or expand a store, warehouse or manufacturing plants are to a great extent determined locally. Moreover, local public procurement is to a large extent determined by local authorities in a city or municipality. Not only the regulations as such, but also the complexity, speed and ultimately the costs imposed on entrepreneurs by local bureaucratic procedures may vary across cities and regions.

Second, nation-wide regulations may still vary across regions in a country because of local variations in the way in which national-level regulations are interpreted and enforced. For example, many 
entrepreneurs witness that there are differences across local authorities in the extent to which they interpret and implement the same regulation in a "business friendly" way.

Third, a large set of studies emphasize that there are locally embedded values and attitudes towards entrepreneurship, exerting a strong influence on entrepreneurial activities at the local level. The wellknown and highly influential study by Saxenian (1994), for example, argued that a prime reason for the success of the Silicon Valley region in California vis-à-vis Route 128 around Boston was to be found in the favorable local or regional "entrepreneurship culture" in Silicon Valley. The concept of regional entrepreneurship culture is often employed to the level of social acceptance and encouragement of entrepreneurs and their activities (see, e.g., Fritsch and Wyrwich 2012 and Beugelsdijk 2007). We may think of such a culture as a type of local informal institution.

These three components of the local institutional setup are clearly inter-related in the sense that they may influence each other in complex ways, and thus co-evolve over time. The local regulations and bureaucracy surrounding businesses in a city may, for example, be a function of the politicians in charge, which in turn depends on how the local population votes. ${ }^{2}$

In what follows, we will discuss the various ways in which these components of the local institutional environment impact the supply and direction of local entrepreneurship. We will cover basic theoretical aspects and also discuss a set of recent empirical research papers that explore the effects of the local institutional environment on entrepreneurship. We also discuss the role the local institutional environment plays in local policies aimed to foster productive (high-impact) entrepreneurship.

The remainder of the chapter is organized in the following way. In section 2 we present our preferred definition of entrepreneurship, emphasizing the distinction between self-employment and entrepreneurship. In this section we also discuss the key distinction between entrepreneurship policy and SME policy. Section 3 presents an overview of the general literature on institutions and entrepreneurship, focusing on the role institutions play for both the supply and direction of entrepreneurship at the aggregate/national level. Section 4 focuses on the local level and discusses the various ways in which the local institutional setup may influence the supply and direction of entrepreneurship. Section 5 summarizes and concludes.

\footnotetext{
${ }^{2}$ People living in an environment with a strong entrepreneurship culture are more likely to vote for "businessfriendly" local authorities.
} 


\section{Entrepreneurship and entrepreneurship policy}

\subsection{What is entrepreneurship?}

Entrepreneurship is about individuals and organizations-be they new, old, large or small-that actively contribute to renewal and change in the economy. This can be either Schumpeterian (Schumpeter 1934) entrepreneurship, which disturbs an existing equilibrium, or it can be Kirznerian (Kirzner 1973) entrepreneurship, which moves the economy towards equilibrium. It does not really matter whether the entrepreneur is the person who provokes change or merely adjusts to it. Entrepreneurial action can mean both creation of opportunity and response to existing circumstances, where entrepreneurs have the wherewithal to embrace risks in the face of uncertainty. ${ }^{3}$

We analyze entrepreneurship as a function carried out by specific individuals, who, by their own volition, decide whether to supply this function. Given that they choose to do so, these activities may be socially productive, unproductive or destructive (Baumol 1990; Murphy et al. 1991). Individuals carrying out the entrepreneurial function are self-serving agents. Thus, they can be expected to venture into the type of entrepreneurship that they expect will lead to the highest private return (broadly construed).

Following Wennekers and Thurik (1999), a person can be said to engage in an entrepreneurial venture if she either on her own or in teams, and either inside or outside existing organizations:

- perceives and creates new economic opportunities (new products, new production methods, new organizational schemes and new product market combinations), and

- introduces her or his idea in the market, in the face of uncertainty and other obstacles by making decisions on location, form and the use of resources and institutions. ${ }^{4}$

Entrepreneurship almost always entails an ambition to grow. This is normally achieved by hiring other factors of production in the market, while the entrepreneur remains the main or sole residual claimant to the excess value created through the new combination of resources. However, the distinctions made above underline why self-employment cannot be equated to entrepreneurship, and why it is likely to be a poor proxy in empirical work. Conversely, employees without an ownership role can also be entrepreneurial (intrapreneurship), although this may be difficult to achieve if it is hard to write compensation contracts that provide the right incentives. More often than not, this is the case, which is a

\footnotetext{
${ }^{3}$ Hebert and Link (2006b) provides an extensive overview of the treatment of the entrepreneur in the economic literature from Richard Cantillon (1680-1734) until the present.

${ }^{4}$ This is closely related to Casson's (2003) definition of the entrepreneur as "a specialist in taking judgemental decisions."
} 
major reason why exceptionally talented entrepreneurs tend to found their own business(es) rather than working as employees in established firms with high-powered incentive contracts. ${ }^{5}$

In Table 1 we identify different motives to start a business. The top row gives society's first-best alternatives. Here, an entrepreneurial business is started because it provides the best vehicle for pursuing a business opportunity. Non-entrepreneurial motives are to give the owner the opportunity to pursue a certain life style, to earn her/his living independently or to facilitate the organization of certain projects best pursued as an independent firm. For instance a franchise could be owned by the manager in order to overcome or mitigate agency problems.

In the second-best case the entrepreneurial motives arise as a result of obstacles barring the optimal outcome. Entrepreneurship provides a means to circumvent obstacles that could emanate either from inappropriate institutions or from within the private sector. For instance, inferior management and business organizations may prevent intrapreneurship. Legislation could ban the use of stock option incentives to encourage intrapreneurship or it could make it prohibitively expensive. Various forms of discrimination often hinder marginal groups from seeking regular employment, leaving self-employment as the remaining opportunity. Becoming self-employed can be a way to evade restrictive employment regulation or pay schedules. Evasive entrepreneurship may also consist of efforts to evade the legal system or to avoid the predatory activities of other agents. Tax evasion and bribes paid to regulators or inspectors used to evade onerous regulations are two examples. Hence, formally illegal evasive activities may in some systems be necessary in order to achieve productive entrepreneurship. ${ }^{6}$

\footnotetext{
${ }^{5}$ Assume for a moment Wal-Mart founder Sam Walton had remained an employee at JC Penney, choosing instead to invest the same fraction of his income in public assets with a risk and liquidity profile similar to Wal-Mart's. It is safe to say that he could not have become the richest man in the world using this strategy. Staunch in his role as employee, Walton could not have retained his billions of dollars' worth of surplus, which he would have had neither the incentive nor the opportunity to create. Any employee contract attempting to decouple ownership, but retain the incentive structure enjoyed by the owner of an entrepreneurial firm would face insurmountable transaction costs.

${ }^{6}$ Van Stel et al. (2007) argue that institutions determine the distribution of business activity between the formal and informal sector of the economy.
} 
Table 1 Entrepreneurial vs. non-entrepreneurial self-employment.

\begin{tabular}{|c|c|c|}
\hline & Entrepreneurial & Non-entrepreneurial \\
\hline First best & $\begin{array}{l}\text { Pursue a business opportunity most } \\
\text { suitably pursued in a new firm. }\end{array}$ & $\begin{array}{l}\text { 1. Seeking independence, a certain } \\
\text { life style etc. } \\
\text { 2. Local service production; working } \\
\text { in networks in temporary projects. }\end{array}$ \\
\hline Second best & $\begin{array}{l}\text { 1. Inferior management by current } \\
\text { employer bars efficient } \\
\text { intrapreneurship. } \\
\text { 2. Mechanism to escape effect of } \\
\text { discrimination or lack of social capital } \\
\text { for marginal groups. } \\
\text { 3. Necessity entrepreneurship. }\end{array}$ & $\begin{array}{l}\text { 1. Safety valve to circumvent } \\
\text { excessive labor market regulations. } \\
\text { 2. Means to achieve flexibility } \\
\text { hindered by other regulations. } \\
\text { 3. Mechanism to escape effect of } \\
\text { discrimination or lack of social capital } \\
\text { for marginal groups. } \\
\text { 4. Necessity entrepreneurship. }\end{array}$ \\
\hline $\begin{array}{l}\text { Unproductive/ } \\
\text { predatory }\end{array}$ & $\begin{array}{l}\text { 1. Set up a business to exploit } \\
\text { subsidies and tax breaks rather than } \\
\text { create value for customers. } \\
\text { 2. Fraudulence. } \\
\text { 3. Looting, warfare etc. }\end{array}$ & $\begin{array}{l}\text { 1. Transform consumption } \\
\text { expenditure into tax deductible } \\
\text { business costs. } \\
\text { 2. Fraudulence, where revenue is } \\
\text { partly unreported etc. }\end{array}$ \\
\hline
\end{tabular}

Note: The table lists the major motives for self-employment. There are also intermediate cases. Entrepreneurial self-employment may, for instance, be partly pursued in search of independence.

In the most unfavorable outcome, the incentives are such that entrepreneurs strive to exploit the business opportunities arising from the regulation itself. Entrepreneurial incentives to start a business may then be geared towards exploiting tax breaks and subsidies rather than creating value. Sidestepping or reducing the impact of taxes and other legislation are also the prime motives for non-entrepreneurial businesses under this kind of regime. In cases where the government does not manage to uphold a monopoly on violence and where the rule of rule law does not prevail, entrepreneurship may also take on highly destructive forms such as looting and private warfare.

In a dynamic economy, novel ideas continuously challenge old structures, thereby giving rise to structural transformation when new successful innovations, products, firms and industries rise, while obsolete ones decline and vanish. Empirical studies point out high-growth firms (HGFs) to be main drivers of this process. Stangler (2010) estimates that one percent of firms in the U.S. create 40 percent of all new jobs in a given year and that five percent of all firms create almost 70 percent of all new jobs. Henrekson and Johansson (2010) survey the numerous studies of firm growth. They conclude that some general findings emerge: 
i) All studies report HGFs to be crucial for net job growth compared to non-HGFs. They generate a large share of all, or more than all (in the case where employment shrinks in nonHGFs), new net jobs. This is particularly pronounced in recessions when HGFs continue to grow, while non-HGFs decline or exit.

ii) Small firms are overrepresented among HGFs, but HGFs are of all sizes. In particular, larger firms are important job contributors in absolute terms. A small sub-group of large HGFs are major job creators.

iii) Age is of great importance. HGFs are younger on average and they are overrepresented in young and growing industries with a large inflow of new firms.

iv) Young and small HGFs grow organically to a larger extent than large and old HGFs, and therefore make a larger contribution to net employment growth.

v) HGFs are present in all industries. If anything, they are slightly overrepresented in service industries.

Haltiwanger, Jarmin and Miranda (2013) show, based on U.S. data, that although it is true that small firms tend to create most of the new jobs, one cannot infer that policy should target small firms and encourage business startups per se. This is due to the fact that, when controlling for firm age, there is no systematic negative relationship between firm size and net job growth. Newly established growth companies tend both to be young and initially small. Most net employment growth takes place in two types of firms: new entrants and young firms that grow from small to large. The category small firms that remain small are not important for job growth, and a large share of them will eventually exit. Close to 50 percent of all net jobs emanating from firm entry disappear within five years due to firm exit, but those firms that do survive tend to grow rapidly. The evolution of young firms thus follows an "up or out" dynamic.

Henrekson and Sanandaji (2014) identify high-impact entrepreneurs from the Forbes Magazine worldwide list of billionaires. Their measure is based on the accumulation of wealth for founders of new business ventures. In this way they identify 996 self-made billionaires who became rich by founding new firms. Using these individuals to construct a per capita rate of high-impact entrepreneurship, they show that this measure is robustly and negatively correlated with self-employment rates, small business ownership rates and the rate of startup activity.

Table 2 summarizes results regarding education and region for the U.S. sample of billionaire entrepreneurs. Billionaire entrepreneurs are highly educated and tend to attend elite universities, indicating ex ante talent. While the 15 highest ranked U.S. colleges account for less than 1 percent of U.S. 
college enrollment, one third of the billionaires graduated from these elite universities. Of the largest entrepreneurial firms in the U.S. founded in the post-war era, one half was founded by billionaire entrepreneurs on the list, indicating that the billionaire measure manages to capture entrepreneurial activity.

California and Massachusetts are strongly overrepresented in billionaire entrepreneurship. Twelve out of 13 Massachusetts based billionaires live in the Boston Metropolitan region or have founded firms active in Boston. Fifty out of California's 99 billionaire entrepreneurs live in or founded firms in the Bay Area. Silicon Valley and Boston are often identified as having above average rates of entrepreneurial activity (Lerner 2009), but compared to the national average these regions had a lower self-employment rate, lower firm density, a lower share of employment in firms with less than 20 employees and a higher share of employment in firms with more than 500 employees (Small Business Administration 2007; Bureau of Labor Statistics 2008).

Table 2 Education and location of American billionaire entrepreneurs.

\begin{tabular}{lrrr}
\hline Educational attainment (\%) & $\begin{array}{r}\text { Billionaire } \\
\text { entrepreneurs }\end{array}$ & $\begin{array}{r}\text { Self- } \\
\text { employed }\end{array}$ & $\begin{array}{r}\text { Salaried } \\
\text { workers }\end{array}$ \\
\hline High School or less & 6.1 & 31.6 & 36.8 \\
Some college & 10.4 & 17.6 & 17.1 \\
College degree & 38.5 & 34.3 & 33.6 \\
Advanced Degree & 45.0 & 16.5 & 12.5 \\
\hline Geographic region & No. & Relative to population \\
\hline Northeast & 109 & & 1.44 \\
(of which New York) & 76 & & 2.85 \\
(of which Massachusetts) & 13 & & 1.45 \\
Midwest & 56 & & 0.61 \\
South & 104 & & 0.71 \\
(of which Texas) & 36 & & 1.17 \\
West & 137 & & 1.48 \\
(of which California) & 99 & & 2.02 \\
\hline
\end{tabular}

Note: Educational attainment refers to population aged 25+. Entrepreneurs are assigned to states based on Forbes' designation. If Forbes did not specify a state this is based on residence. Relative to population is defined as the share of total entrepreneurs divided by the population share of the state/region 19962009.

Source: Henrekson and Sanandaji (2014). 
We thus argue that entrepreneurship cannot be equated to self-employment or small business activity more generally. Moreover, the evidence suggests that high-impact entrepreneurship (HIE; Acs 2008) is particularly important. High-impact entrepreneurial activities commercialize key innovations or create disruptive breakthroughs, extract substantial entrepreneurial rents, spur growth (in both the firm and the economy) and employment, and shift the production possibility frontier outwards. Yet a typical startup is not characterized by HIE; and high-impact entrepreneurship is not necessarily performed within new (or small) firms.

How entrepreneurship is conceived and measured is of course crucial for how policies aimed at promoting productive entrepreneurship are designed and implemented. The remainder of this chapter will deal with that issue; first at the national and then at the regional and local level.

\subsection{Entrepreneurship policy vs. SME policy}

Entrepreneurship can be encouraged by efforts ranging from specific targeted support, such as technology assistance to small firms, to general macro policies to maintain a stable economic environment. Given the distinctions between entrepreneurial and non-entrepreneurial self-employment pointed out in the previous subsection, entrepreneurship policy cannot be equated to policy encouraging self-employment or small business activity, often called SME policy (Lundström and Stevenson 2002). The aim of entrepreneurship policy should not be to stimulate firms but to support an economic system that encourages socially productive entrepreneurial activity irrespective of business form. Moreover, as it is difficult - if not impossible - for policy makers to a priori determine who will be an entrepreneur, measures directed at a specific group or a specific form of business are largely misdirected (Holtz-Eakin 2000). Nor should public policy try to influence the "natural" evolution of firm size, growth, or form through targeted subsidies or tax breaks. Market forces and profit motive alone should govern the evolution of firms. Unless a substantial market failure that can be rectified through public policy exists, targeted programs should be looked upon with skepticism. A system replete with special treats and regulations for select categories results in a complex system with detailed rules, exceptions, and exceptions to the exceptions. In the end, this impairs all activity because of increased administration and information costs. Complex systems also provide opportunities for unproductive and destructive entrepreneurship.

Normally, welfare increases if the economy allows and rewards productive entrepreneurial initiatives across the board, independent of firm and individual characteristics. A well-designed entrepreneurship 
policy facilitates productive entrepreneurial activities and enables the creation and commercialization of valuable knowledge (Acs and Szerb 2007; Braunerhjelm et al. 2010). Whether this implies a high or low rate of self-employment or SMEs is largely irrelevant. Instead of focusing on quantitative aspects of entrepreneurship, entrepreneurship policy should focus more on the qualitative aspects. Empirical evidence suggests that an economy that fosters (a few) high-impact entrepreneurial firms and highgrowth firms is superior to an economy that tries to maximize the number of SMEs or the rate of selfemployment (Shane 2008; Henrekson and Sanandaji 2014). Figure 1 depicts the major distinctions between SME policy and entrepreneurship policy.

Figure 1 SME policy vs. entrepreneurship policy.

\begin{tabular}{|l|}
\hline SME Policy \\
Entrepreneurship Policy \\
\hline
\end{tabular}

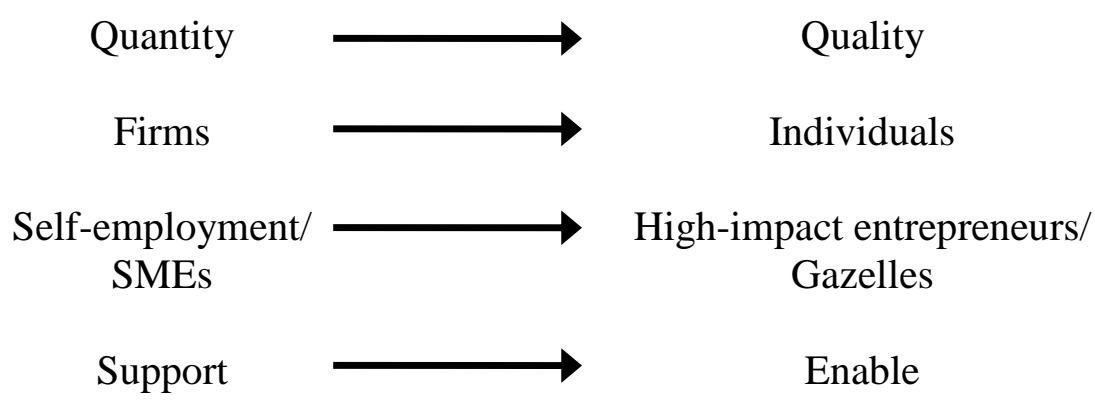

Nonetheless, the entrepreneur is not the only agent important for economic progress. Successful entrepreneurs who identify and exploit new ideas - thereby creating and expanding businesses-depend on a number of complementary agents, such as skilled labor, industrialists, venture capitalists and secondary markets. Successful entrepreneurs cannot succeed without these complementary competencies and inputs. ${ }^{7}$ Focusing on just the entrepreneur distracts from important factors necessary for an economy to prosper. Still, entrepreneurship is crucial; a lack of productive entrepreneurs cannot be fully offset by an ample supply of skilled labor or an extensive capital market.

\footnotetext{
${ }^{7}$ Johansson (2010) and Henrekson and Johansson (2009).
} 


\subsection{The supply and direction of entrepreneurship}

We agree with Baumol's (1990) point that entrepreneurship can be productive, unproductive or destructive depending on the "social structure of payoffs". However, in our view his assumption that the supply of entrepreneurship is constant, while its allocation across activities is the only thing that varies, is untenable. Similar to other economic inputs, entrepreneurship is valuable and scarce (Schultz 1979), has a definable—although hard to measure-quantity, and a shadow market price.

The entrepreneur often "creates" the capital of the firm by investing in tangible and non-tangible assets that in time create a return, such as developing the product and building firm structures. At any given moment, this capital requires a continued commitment on the part of the entrepreneur, whether or not it is sold externally at value. The growth of the firm is often financed through retained earnings until the point when the firm is sufficiently developed so that it can be sold, or produce cash flow that can be withdrawn by the owner without being detrimental to the firm. Thus, the quantitatively important saving decision does not constitute the initial capital injection, but rather the fact that entrepreneurs refrain from withdrawing the equity value of their firms before they have matured in terms of production efficiency and asset tradability.

The entrepreneur is rewarded for both effort and the postponement of consuming firm equity into an uncertain future. But the earnings of owners-managers are likely to be more complicated than a simple additive sum of capital and labor. Successful entrepreneurial firms need several components that are hard or nearly impossible to purchase externally. These include product or business ideas, sufficient managerial skills to implement innovations, and the willingness to exert time and effort to realize an uncertain outcome. Because of well-known agency costs, entrepreneurs must provide a significant share of requisite capital themselves. Lastly, these requirements must be combined with the postponement of consumption (and additional risk taking) in one individual-the entrepreneur. The inability to decouple saving, investment and effort requires that entrepreneurial talent and opportunity intersect, unlike labor and capital markets. As a result, the supply of entrepreneurship tends to be more constrained than the supply of labor or financial capital. This explains the above-market returns earned by entrepreneurs (controlling for capital and labor output). Moreover, potential entrepreneurs with high-quality ideas and talent are few and far between. High risk, high uncertainty, large demands on effort, lack of access to capital markets, and long time lags before expected returns reduce the number even more. This is especially true since the best potential entrepreneurs tend to have the most valuable outside options. 
In short, the supply of entrepreneurship is likely both to be elastic-good prospects and profit opportunities bring forth more entrepreneurial effort-and its allocation across more or less socially beneficial activities to be governed by the rules of the game. Thus, we find it fair to hypothesize that both the volume of entrepreneurial effort and its allocation are determined by the institutional setup.

\section{Entrepreneurship policy: the national level}

The main purpose of this chapter is to discuss the effect of local institutions for entrepreneurship and the local business climate. Still, however astute politicians and other policymakers are in designing favorable local conditions, they are still constrained by the national framework conditions. The local policies and institutions are always developed and maintained within the confines of the national framework. Heeding this fact, we discuss a set of important national institutions before turning to the local level. The discussion is by no means exhaustive. Our aim is simply to provide a context within which local institutions and policies may be evaluated and discussed. Important areas not discussed include the functioning of capital markets, systems for targeted support and bankruptcy law. For a more comprehensive discussion the reader is referred to Baumol et al. (2007), Henrekson and Stenkula (2010) and the various contributions in Audretsch, Grilo and Thurik (2007).

\subsection{Pertinent institutions at the national level}

By now there is a fairly large empirical literature aiming to identify the effect of various institutions and policies on the rate of entrepreneurial activity. It is beyond the scope of this chapter to give a complete overview of this literature. However, it is important to make a number of points in order to make clear the extent to which local/regional and national policies and institutions (both formal and informal) interact and reinforce one another. A good starting point is Baumol et al.'s (2007) four primary tenets underpinning an entrepreneurial economy:

- ease of starting and growing a business;

- generous rewards for productive entrepreneurial activity;

- disincentives for unproductive activity, and

- incentives to keep the winners on their toes. 
Empirical observations have illustrated that entrepreneurs behave differently than comparable wage earners. For instance, by having a higher income elasticity with respect to taxes (e.g., Sillamaa and Veall 2001; Chetty et al. 2011; Saez 2010). Firm growth, investment, hiring of outside labor and personal effort have all been shown to be significantly affected by taxes (Rosen 2005).

In what follows we will highlight what we consider to be the most pertinent institutions and policies determining the extent to which a productive entrepreneurial economy is fostered. However, the discussion will not be exhaustive, since the main contribution of this chapter should be a discussion of local institutions and policies fostering entrepreneurship.

\subsection{The rule of law and the protection of property rights}

Based on broad historical studies (e.g., Rosenberg and Birdzell 1986) and more recent econometric work (e.g., Rodrik et al. 2004 and Acemoglu and Johnson 2005), it is now widely recognized that protection of private property rights is of fundamental importance for economic growth (Besley and Ghatak 2010). With secure exclusive private property rights which can be used in voluntary exchanges based on contracts, productive entrepreneurship is likely to thrive. Then successful entrepreneurs know that they will retain the profits they earn. Specialization and the division of labor is also greatly facilitated, which broadens the range of potential entrepreneurial combinations to be discovered or created.

Weaker property rights will spur other types of entrepreneurship including the production of (increasingly diverse and sophisticated) private security services. The weaker the property rights, the more predatory the entrepreneurial activities are likely to be.

In some cases innovativeness and entrepreneurship may also be stifled by overly strong property rights protection. An important contemporary example is the strong intellectual property rights protection of high-tech patents, which allegedly gives large incumbent firms a competitive advantage relative to entrants and potential competitors. Incumbents are said to spend large resources on defensive patenting and purchases of patents from small innovators in order to reduce competition, or if firms file patents for ideas, business models, software strings etc. that are obvious and have been around for quite some time without somebody having tried to patent them before (Cohen 2005). As argued by Gans and Persson (2013) strengthened property rights protection does not always go hand in hand with innovative entrepreneurship. Instead competition policy should have a complementary role in promoting innovation in order to keep winners on their toes. 


\subsection{Tax policy}

Income from entrepreneurial activities is not a separate income category in the tax code. Hence, from a tax perspective entrepreneurial income can show up in many different forms: labor income, dividends, capital gains, capital gains on stock options, interest income on lending by the entrepreneur to his/her own business and so on. ${ }^{8}$

Given the complexity of the tax code in a typical OECD country the incentive effects of the tax code on entrepreneurial behavior are also highly complex. Some features are likely to be of particular relevance. By the 1970s effective tax rates on business income came to differ tremendously by source of finance and ownership category in rich countries. Debt was the most tax-favored form of financing, and new equity issues the most penalized. Business ownership positions held directly by individuals and families were taxed much more heavily than other ownership categories. The wave of tax reforms that swept the OECD in the 1980s reduced these differences (Jorgenson and Landau 1993).

Differences in effective tax rates have potentially powerful effects on the organization of business activity and the industry mix of productive activity, and therefore also on the incentives for entrepreneurship. To the extent that debt financing is less costly and more readily available for larger and firmly established incumbents, high statutory tax rates coupled with tax-deductible interest payments work to the disadvantage of smaller firms and potential entrepreneurs. Debt financing is also more easily available to firms with ready forms of collateral. This favors capital-intensive industries and modes of production relative to labor and knowledge intensive ones, which is likely to work to the detriment of entrepreneurial, often equity-constrained, firms.

To a large extent the return on entrepreneurial effort is taxed as wage income. First, the tax code may restrict the extent to which income accruing from closely held companies may be taxed as capital income. Second, a great deal of the entrepreneurial function is carried out by employees without an ownership stake in the firm, and for them the labor tax schedule applies.

A further mechanism to encourage and reward entrepreneurial behavior among employees is stock options. The efficiency of stock options is highly dependent on the tax code. If the gains on stock options are taxed as wage income when the stock options are tied to employment in the firm this mechanism will lose much of its incentive effects. The situation would be very different if an employee who accepts

\footnotetext{
${ }^{8}$ This section largely builds on Henrekson and Sanandaji (2011).
} 
stock options can defer the tax liability to the time when the stocks were eventually sold. This effect would be further reinforced if there are no tax consequences to the employee upon the grant or the exercise of the option and if the employee is taxed at a low capital gains rate when the stock acquired from the exercise of the option is sold. In the latter case the tax risk of the options are pushed back to the government. This increases the potential profit from the stock options and it allows budgetconstrained individuals to sell stocks whenever they chose to do so. The U.S. changed the tax code in the early 1980s along the latter lines, which paved the way for a wave of entrepreneurial ventures in Silicon Valley and elsewhere.

Venture capital firms can also play a crucial role in the development of a small entrepreneurial venture by converting high-risk opportunities to a more acceptable risk level through portfolio diversification, and adding key competencies that the firm may be lacking. This is achieved by arrangements that align the incentives of the three agents-investors, venture capitalists and entrepreneurial startups (Gompers and Lerner 2001). The extent to which this is possible is also largely governed by the tax code for stock options, capital gains, and whether pension funds are allowed to invest in high risk securities issued by small or new companies and venture capital funds.

A further effect may be that certain actors such as private equity firms can act from offshore tax havens putting them at an advantage relative to individual entrepreneurs. If this effect is present it is increasing with respect to the effective tax rates levied on entrepreneurs legally domiciled onshore.

To sum up, high taxes may spur self-employment but reduce productive entrepreneurship. ${ }^{9}$ On the other hand, a high aggregate tax rate is normally associated with a generous welfare system, which reduces the push into self-employment. Moreover, high tax rates encourage entrepreneurship in the black market and evasive entrepreneurship. But most importantly high effective tax rates tend to benefit large incumbent, capital intensive firms that can have high debt-equity ratios and be owned by institutions, in particular if they are domiciled in tax havens. All in all there is reason to believe that high taxes stifle productive entrepreneurship, although this effect can be greatly mitigated if the taxation of capital gains and stock options is low.

\footnotetext{
${ }^{9}$ Schuetze and Bruce (2004) and Henrekson and Sanandaji (2014).
} 


\subsection{Labor market institutions}

The churning of firms and jobs is a ubiquitous feature of modern economies. The extent of this dynamism is illustrated in Table 3 with data for the U.S. economy averaged over almost three decades. The number of new jobs per year is as high as 18 percent of the total number of jobs. One third of these new jobs are created in new establishments and two thirds through the expansion of existing establishments. At the same time, 16 percent of all jobs are lost through the closure and contraction of some establishment, resulting in an annual net job growth rate of 2 percent.

Table 3 Job creation and destruction, U.S. annual averages 1977-2005.

\begin{tabular}{lr|lr}
\hline Job creation by entry & $6 \%$ & Job destruction by exit & $6 \%$ \\
Job creation by expansion & $12 \%$ & Job destruction by contraction & $10 \%$ \\
Gross job creation & $18 \%$ & Gross job destruction & $16 \%$ \\
\hline Job reallocation rate (gross job creation + gross job destruction) $=18+16$ & $34 \%$ \\
Net job growth (gross job creation - gross job destruction) = 18 - 16 & $2 \%$ \\
Excess job reallocation rate (job reallocation rate - net job growth) = 34 - 2 & $32 \%$ \\
\hline
\end{tabular}

Source: Davis et al. (2008).

Thus, a net gain of 2 percent in the number of jobs is associated with a gross job reallocation rate of 34 $(18+16)$ percent. The excess job reallocation rate-the amount of job churning over and above the minimum required to accommodate the net employment change-equals 32 percent. Extensive churning is a pervasive trait of all OECD economies (Martin and Scarpetta 2012). 80 percent or more of the reallocation of workers takes place within narrowly defined sectors of the economy in developed countries (Caballero 2007). Moreover, excess job reallocation rates are higher for newer plants because of greater uncertainty, more experimentation and higher variance in quality of the goods produced.

Labor market and wage-setting regulation can influence incentives for entrepreneurship since it restricts the freedom of contracting and therefore curtails possible combinations of factors of production. Labor security regulations fall more heavily on younger, smaller, and less capital-intensive employers. As entrepreneurial firms are overrepresented in these categories, labor security regulation disproportionally burdens entrepreneurial firms.

Employment flexibility is likely to be important for entrepreneurial activities. Strong regulation of the employment and dismissal of employees keeps entrepreneurs from adjusting their workforce in correspondence with market fluctuations, thereby increasing the risk of their projects (Audretsch et al. 
2002). As an employer determines a worker's abilities over time, and as those abilities evolve with the accumulation of experience, his optimal work assignment will also likely change. As Table 3 tells us this often entails worker mobility between firms; such mobility is more likely to occur when the initial employment relationship was forged in a small, often young, business.

A low level of labor market regulations increases the flexibility of high-risk entrepreneurial companies, making it more attractive to be an entrepreneur. Moreover, the relative advantage of being an employee decreases with weak employment protection laws, making it more favorable to undertake entrepreneurial projects as self-employed. Generous, far-reaching labor protection laws also increase an employee's opportunity cost of changing employers or leaving a secure salaried job to become selfemployed.

The extent of labor market regulations differs greatly across countries (Skedinger 2010). New research has found that the differences in labor market regulations shape the level of nascent entrepreneurship more than entry regulations. Entrepreneurship tends to be higher in countries where it is relatively easy to hire and dismiss employees (van Stel et al. 2007).

Labor market deregulation can and has stimulated entrepreneurial activities in many OECD countries. Small firms in the Netherlands, for example, hire fewer employees than needed due to the perceived cost of formal rules and regulation. New firms in the U.S. on the other hand, expand their employee base more rapidly than firms in Europe (OECD 2003). Europe's stricter employment protection laws probably induce the relative lack of new, rapidly growing firms in Europe (Baumol et al. 2007, p. 210ff).

Several European countries have thresholds where labor regulations become more onerous once the size of the firm exceeds a certain limit. This is equivalent to a tax on firm growth. For instance, when French firms reach 50 employees they must form work councils, give more union representation and face higher firing costs. As shown by Garicano, Lelarge and Van Reenen (2013) this created reluctance among many firms to move beyond that limit. Portugal and Italy have important regulatory limits at 15 employees, which have been shown to have similar growth-impeding effects (Braguinsky, Branstetter and Regateiro 2011; Schivardi and Torrini 2008). Thus, firms are incentivized to remain small and many entrepreneurs will not discover that they in fact had the ability to become high-impact entrepreneurs, because they do not even try.

If regular employment is highly regulated there are incentives to circumvent these regulations. Potential entrepreneurs can do so by pursuing entrepreneurial projects as self-employed, using only self-employed 
labor instead of hiring employees if labor is needed. Compensation and working hours are totally unregulated and no labor security is mandated for the self-employed. This may boost the level of selfemployment, but it is not a sign of exuberant entrepreneurial activity; it is a costly, albeit necessary, measure to evade the effects of stringent labor market regulation.

Given the large intra-firm differences in productivity and productivity growth, wages set in negotiations away from the workplace that do not take idiosyncratic factors into account will impair entrepreneurial activities. Intra-firm differences are especially large in young and rapidly expanding industries and firms (Caballero 2007). In developed countries, employees' general income level is also relatively high, which in turn makes the opportunity cost of leaving salaried employment to start or work in a new venture high as well (Ho and Wong 2007).

To summarize, a tightly regulated labor market may create a system in which a large share of economic activity occurs in small firms lacking the ability or the ambition to grow. Onerous regulation makes it difficult and risky to build large companies. Italy is a good case in point, where firms tend to remain small and resort to cooperating with other small firms in clusters (Lazerson and Lorenzoni 1999). By contrast, new firms in the U.S. tend to expand their businesses more rapidly than their European counterparts.

\subsection{The social insurance system}

By providing insurance for unfavorable outcomes, an extensive and generous public social insurance system can in principle encourage individuals to pursue entrepreneurial endeavors (Sinn 1996). At first sight, it seems clear that a generous welfare system should make it less costly to bear uncertainty as an entrepreneur or to move to a risky job in an entrepreneurial firm. In labor markets where job security is closely linked to job tenure, this may no longer hold; what matters is the opportunity cost, or how much an employee has to give up in terms of income security if (s)he transfers to self-employment or a risky job in an entrepreneurial firm. For a tenured employee with a low-risk employer, the opportunity cost rises considerably in many OECD countries.

In many countries important benefits are tied to employment, such as health insurance in the U.S. Many workers and potential entrepreneurs get "trapped" in large companies that provide generous health insurance. Decoupling health insurance from employment would increase labor flexibility and reduce fears of losing adequate health insurance and other important benefits that may be tied to employment. In Denmark, generous welfare systems are combined with weak job security mandates, "flexicurity" 
(Andersen 2005). This can be contrasted to Sweden, where somebody who voluntarily gives up a tenured position for self-employment may end up having no more security than what is provided by (meanstested) social welfare. Hence, the construction of the public income insurance systems in combination with the employment security legislation tends to penalize individuals who assume entrepreneurial risk.

Furthermore, the manner in which savings are channeled to various investment activities influences the type of business organization that can obtain credit. Pension funds are less likely to channel funds to entrepreneurs than business angels or venture capital firms. Hence, the composition of national savings is not neutral in its impact on entrepreneurship and business development. If the government forces individuals to keep a large part of their savings in a national pension fund system, small business credit availability will suffer relative to an alternative policy and institutional arrangements that allow for greater choice by individuals regarding their savings and investments.

A final point concerns the design of supplementary pension systems. Supplementary pension plans that are not fully actuarial and individualized contain elements of redistribution and risk-sharing across individuals in a group, like white-collar workers in a certain industry. The pension benefit level may be disproportionately tied to the wage level achieved towards the end of the professional career. Moreover, it may be difficult to transfer the accumulated pension assets when switching employer or industry. To the extent that this is true, the mobility of (especially more senior) workers across firms is hampered and the hiring of elderly unemployed is discouraged.

\subsection{Institutions and policies at the national level: concluding thoughts}

It should once more be emphasized that this section on institutional factors determining the climate for productive entrepreneurship at the national level is far from exhaustive. It should just be seen as a backdrop, albeit a necessary one, to the discussion of local determinants in the ensuing section. When reading the next section it is important to keep in mind that the aggregate level of productive entrepreneurship in a nation and its leverage when combined with other complementary factors of production is largely determined by national factors. The fact that one may still find pockets of dynamic entrepreneurship in the impoverished south of Italy and the quickly depopulating north of Sweden should not be taken as evidence against this view.

On the other hand, the aggregate level of entrepreneurship in a country is the sum of entrepreneurial activity in the numerous local communities. As we will see, there is plenty of room for local initiatives 
and policies to improve the entrepreneurial climate locally. Potentially, this gives rise to healthy institutional competition at the regional level, which improves the climate for entrepreneurship in many locations.

At the national level the greater part of the institutional setup is determined through democratic decision making. And if pro-competitive/pro-entrepreneurship policies can be shown to boost job creation, social welfare and the quality of life, people are more likely to vote for politicians prone to make the institutional setup more favorable for productive entrepreneurship. Obviously, the reverse is also true: If current policies and institutions favor unproductive and predatory entrepreneurship, economic performance will be dismal, and political demands will be raised to curtail predatory entrepreneurship. The ensuing reforms may at least partly succeed in that respect. But if reforms are not designed wisely, if they merely curb the scope for predatory entrepreneurship without providing favorable incentives for productive entrepreneurship, the result could be stagnation.

\section{The local level: institutions and entrepreneurship policy}

In the previous section we discussed at some length a number of pertinent institutions and policies which have been identified as important determinants of the rules of the game for entrepreneurship at the national level. Here we discuss the local level and argue that there are a number of institutional framework conditions for entrepreneurship that are determined as well as operate at the local level.

We start by providing a general argument for why local institutional conditions are important for entrepreneurship. We then discuss the extent to which formal institutions in the form of taxes and regulations can be influenced by local authorities, and survey the (still fairly few) studies of the effect institutional characteristics on the local business climate and entrepreneurial activity. This is followed by a discussion of local informal institutions, focusing on the influence of the attitudes and the general level of social acceptance towards entrepreneurship. Finally, in the last subsection (4.4) we synthesize and discuss what aspects of the local institutional environment are critical for the local version of entrepreneurship policy as defined in Figure 1. 


\subsection{Why the local level matters and the general case for the importance of local institutions} for entrepreneurship

Spatial variations in entrepreneurship are large even among local jurisdictions embedded in the same national (or federal) institutional environment. The literature on the "Geography of Entrepreneurship" has for a long time documented substantial inter-regional differences in the rates of new firm formation (Audretsch and Fritsch 1994; Armington and Acs 2002). Notwithstanding the issues associated with proxying entrepreneurship with the raw startup rate discussed in the previous sections, we can illustrate the main point by looking at the differences in startup rates across Swedish municipalities (Figure 2).

Figure 2 The variation in startup rates across Sweden's 290 municipalities in 2007 (per 10,000 inhabitants aged 16-64).

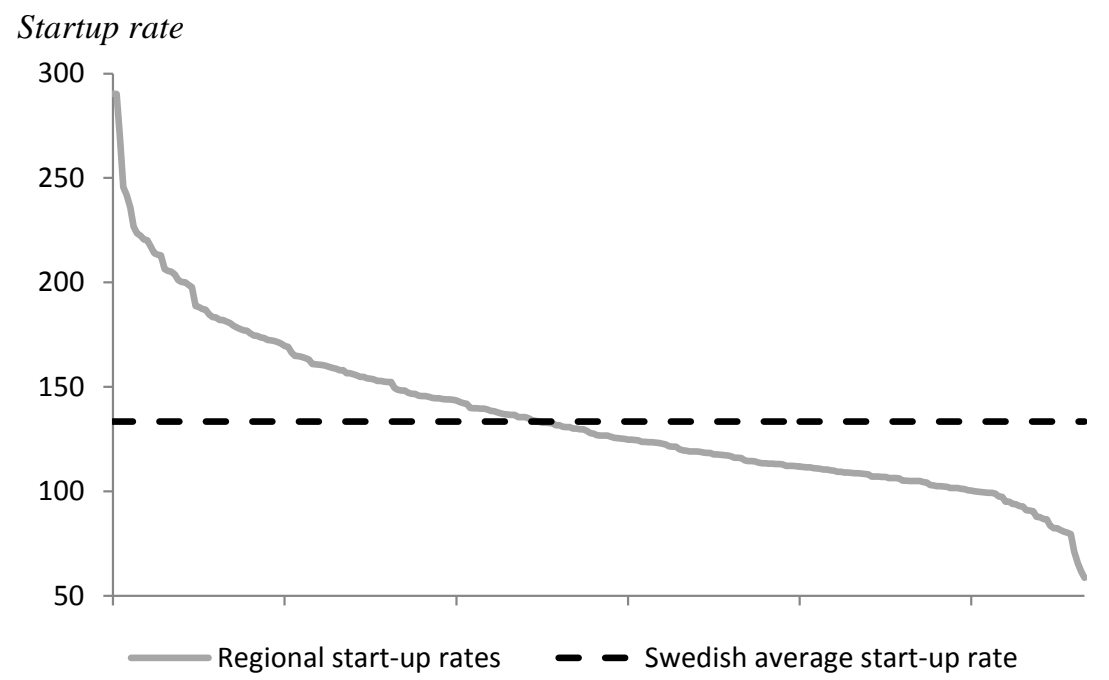

Source: Andersson (2012).

Municipalities (ranked in descending order)

We first calculate the number of new establishments per 10,000 inhabitants (16-64 years of age) in every municipality in Sweden and then rank them in descending order according to their startup rate in 2007. The horizontal dashed line represents the national average, which amounts to about 130 new establishments per 10,000 inhabitants. The solid line yet shows that across municipalities, the startup rate ranges from just over 50 to nearly 300 . This implies that the inter-municipal variation in startup rates amounts to a factor of almost six. ${ }^{10}$

\footnotetext{
${ }^{10}$ Startup rates are here measured as the number of new establishments normalized by the regional population in the age interval 16-64.
} 
These spatial variations do not reflect a transitory structure. Longitudinal analyses reveal a high persistence over time. Figure 3 presents the relationship between the startup rate in 2007 and in 1987 across Swedish municipalities, i.e., over a time span of two decades.

Figure 3 The relationship between startup rates in 2007 and 1987 across Swedish municipalities (new establishments per inhabitant aged 16-64).

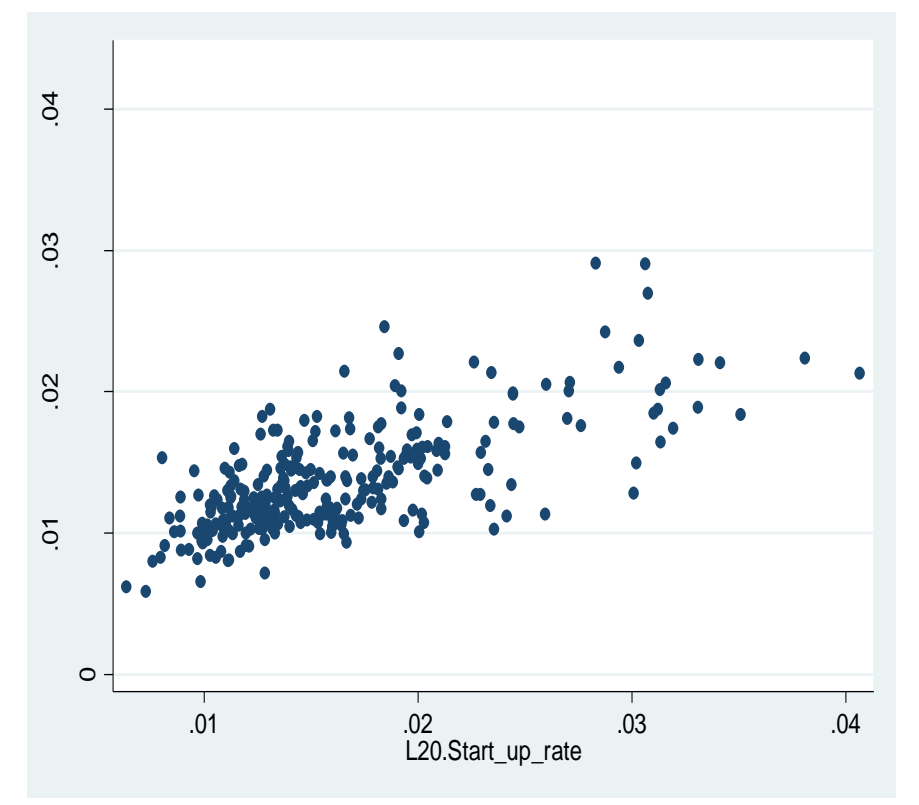

Source: Andersson (2012).

It is clearly the case that there is persistence in the geography of startup rates. Municipalities with high startup rates in 2007 are typically those that had high startup rates two decades before. Indeed, a simple ordinary least square estimation of the relationship in Figure 3 shows that the startup rate 20 years before is capable of accounting for roughly 50 percent of the current variance in startup rates across municipalities.

The large variation in startup rates across municipalities cannot be explained by national regulations. Potential explanations for the observed pattern must be sought at the subnational level. It may, for instance, reflect persistent spatial variations in the supply of individuals with entrepreneurial skills, differential availability of various types of inputs and supporting structures for entrepreneurs, customer base, local knowledge spillovers and labor force composition as well as differences in the local formal and informal institutional setup (cf. Glaeser 2007). Even if the institutional setup is only one of several 
potential determinants of local entrepreneurship, there are strong arguments in favor of the view that it is a critical factor.

Conceptually, the overall role of local institutions for entrepreneurship can be demonstrated by distinguishing between two main effects (Acs et al. 2008): (i) a direct effect understood as the influence of local institutions on the incentives and returns to productive entrepreneurship amongst local firms and individuals; and (ii) an indirect effect reflecting that entrepreneurial firms and individuals may selfselect to locations with an institutional environment favoring productive entrepreneurship (see Figure 4). The indirect effect refers to spatial sorting and implies that institutions influence the local supply of entrepreneurs.

While the same type of effects to some extent also apply at the national level, they are particularly important in a local context. The spatial mobility of firms and individuals is generally higher at subnational levels, which implies a stronger potential for indirect effects. ${ }^{11}$ Therefore, the effects of the institutional environment for entrepreneurship could be argued to be especially high at the local level.

A change in local business regulations, for example, will not only impact on entrepreneurial undertakings of firms and individuals already in the locality; it may over time also bring about an inflow of entrepreneurs who are attracted by a more favorable environment for entrepreneurship. Likewise, a deterioration of the institutional setup may reduce the incentives for productive investments among existing businesses, while at the same time reducing the local supply of entrepreneurs, i.e., entrepreneurs may choose to relocate to other places or abstain from entrepreneurship altogether. There are indeed claims that entrepreneurial people are innately mobile and flexible and that being alert to opportunities is a defining trait of entrepreneurship (Kirzner 1973). As a result one may hypothesize that entrepreneurial talent will flow to locations where the business climate is more favorable.

\footnotetext{
${ }^{11}$ Migration rates between regions belonging to the same country are for example an order of magnitude higher than the rates of international migration.
} 
Figure 4 Direct and indirect effects of the local institutional framework on entrepreneurship.

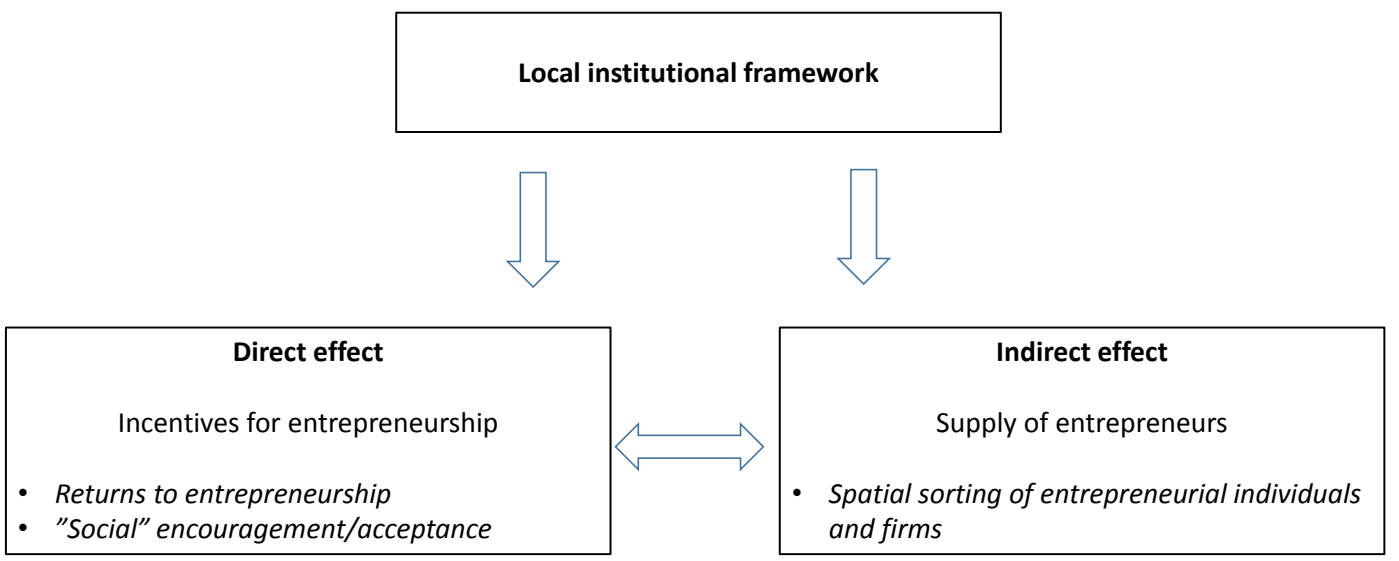

The key point is that changes in the institutional framework for entrepreneurship at the local level imply changes in the relative returns to productive entrepreneurship across regions. These spatial variations in returns may induce a response over time where entrepreneurial firms and individuals sort themselves to location offering better returns. The indirect effect amplifies the influence of local institutions on entrepreneurship.

\subsection{Local variations in formal institutions - taxes and regulations}

The extent to which formal local institutions matter is of course linked to whether pertinent institutions, such as taxes and regulations, are determined at the local level. If we define "local" as referring to the subnational level in general, it becomes clear that it is necessary to distinguish between federal and nonfederal states. In general, local authorities in the former regime have greater influence on the local institutional setup. But as we will show, local authorities can play an important role in non-federal states as well.

\section{Taxes}

As regards taxation, an area of crucial importance for the returns to entrepreneurship (section 3.3), corporate taxes are under non-federal regimes most often solely determined at the national level and consequently do not show any spatial variation. Thereby they are by definition not a distinct feature of the local environment. In federal states, however, they can differ significantly across different parts of the country. U.S. states are for example entitled to impose taxes on businesses and there are also significant 
interstate differences in business taxation. Given the wealth of evidence on the effect that corporate income taxes have on entry (e.g., Da Rin et al. 2011), it follows that inter-state variations in business taxes may be one reason for differences in entrepreneurship across U.S. states. Papke (1991) indeed finds a significant effect of business taxes on the location of startups in U.S. manufacturing, though the responsiveness to tax differentials tends to vary significantly across industries. Kolko et al. (2013) also show that state-level business climate indexes emphasizing taxes and costs in general do a better job than other indexes in predicting economic growth across states. Decomposing the tax-and-cost indexes, they further identify corporate taxation as one of the components that matters the most.

In contrast to corporate taxes, income taxes are often largely determined locally in non-federal states as well, and vary across local jurisdictions. In Sweden, for instance, local governments play an important role in public finances, and as in many other countries, local income taxes are used to finance local public services such as health care, schools, child care, and care of the elderly. ${ }^{12}$

Income taxes are of course not directly related to businesses in the same way as corporate taxes, but they may still have effects on local entrepreneurship. Successful and wealthy entrepreneurs with high incomes may be repelled by high income taxes, thus reducing the local supply of entrepreneurs (e.g., Haughwout et al. 2004). Even entrepreneurs in low-skilled industries who choose sole proprietorship as the legal form may be more inclined to choose cities with low income taxes as their place of residence. The profits earned by these types of firms are taxed in the context of the income tax bills of the owner. This type of "solo entrepreneurs" are, at least in theory, foot-loose and may save on taxes by moving themselves (and thereby their firm) to municipalities with lower income taxes. At the same time, high local income taxes could stimulate new firm formation. Self-employment through incorporated businesses, for instance, provides more scope for taxing business profits at the capital gains and/or dividend tax rate rather than as labor income (Edmark and Gordon 2013). The latter tax rate is normally considerably higher. Therefore, in places with high income taxes, the relative gains from selling your services as an entrepreneur rather than as an employee may be higher.

\footnotetext{
${ }^{12}$ Local income taxes are a substantial part of total taxes on labor in Sweden. In 2011, the local income tax of municipalities accounted for about 45 percent of the total income tax (including mandatory social security contributions). Moreover, nearly 60 percent of total tax revenue consisted of tax on labor income including tax on pensions and other taxable transfers (Tax Statistical Yearbook of Sweden 2013).
} 
Studies on Swedish data generally find negative correlations between local income taxes and broad measures of entrepreneurship. High municipal income tax rates are for example negatively associated with the frequency of startups and immigration of firms from other regions (Daunfeldt et al. 2013), as well as with the growth of the local private sector (Fölster and Peltzman 2010). However, it is difficult to ascertain whether the estimated influence of local taxes reported in these studies reflect an influence of taxes per se, or rather an influence of a wider set of local policies that correlate with the level of local income taxes.

It should also be stressed that the effect of taxes in a local context is complex, especially when acknowledging both the direct and indirect effects. High taxes may increase the costs imposed on firms as well as individuals. Yet, if those taxes finance high-quality local public services, such as good schools, safe streets and excellent healthcare, they may also make the region more attractive for both firms and individuals.

\section{Regulations}

Regulations can be defined as "... the diverse set of instruments that governments use to impose requirements on enterprises and citizens" (OECD 1997, p. 196). They include "laws, formal and in formal orders and subordinate rules issued by all levels of government, and rules issued by non-governmental or self-regulatory bodies to which government have delegated regulatory power" (ibid., p. 196).

In general, local authorities have a large impact on regulations. In some areas they have the authority to design regulations locally. In other areas they are responsible for enforcing nationally-enacted regulations, but may do so with varying stringency and methods of enforcement. Tannenwald (1997, p. 83) lists five general areas of regulation that have a direct impact on businesses and where state authorities in the U.S. have substantial influence:

- Environmental protection and land use.

- Regulation of labor markets and the workplace.

- Regulation of financial institutions.

- Energy production, distribution, and conservation.

- Transportation. 
With the exception of regulations concerning labor markets, workplaces and financial institutions, these are areas typically also influenced by local authorities in non-federal states. Zoning is a prime example. The vast majority of countries allow (or require) local authorities to use zoning as a device for land-use planning (Larsson 2006). Zoning regulations stipulate which types of activities that are permitted at various locations in a municipality or county. They also determine the extent of activities in terms of parameters such as space, density, height and requirements of open space. Zoning regulations also apply to many different types of activities: residential housing, commercial buildings, agriculture and industrial production.

Zoning is also likely to have a broad impact on local entrepreneurship through both direct and indirect effects. It is clear that ill-designed and badly implemented zoning regulations weaken incentives to entrepreneurship by working as a major barrier of entry for new entrepreneurs as well as a barrier to business expansion for incumbents. They may also reduce the supply of productive entrepreneurship in many different ways. Entry barriers caused by zoning could, for instance, repel entrepreneurs such that they instead choose to expand or set up new businesses elsewhere. A second effect may run indirectly through housing and local consumer service sectors. Residential land-use restrictions may result in a municipality or county not being able to exploit natural advantages like sea-shores and lake-sides to build attractive housing, which lowers the attractiveness of the location for employees and entrepreneurs alike. $^{13}$

The influence of local governments on regulations is amplified by the fact that how a given set of regulations are implemented in practice is at least as important as how they are codified in writing. On top of local variations in the formal regulatory environment, there may be differences between local authorities also in terms of how regulations (including nation-wide regulations) are enforced. In this vein, Tannenwald (1997, p. 84) rightly states that “... controlling for enforcement behavior is more important in evaluating the impact of regulation than the impact of taxation. Yet, measuring regulatory stringency is generally more difficult than measuring the burden of taxation."

It is indeed a daunting challenge for empirical analysts to assess local variations in enforcement of regulations. Available evidence still points to quite large effects. Bertrand and Kramarz (2002) directly

\footnotetext{
${ }^{13}$ Moreover, regulations concerning commercial buildings and entry of stores in a city may imply higher retail prices as well as a less vibrant and diversified sector for retailing and other consumer services, which is likely to influence the city's attractiveness.
} 
estimate the impact of how strictly commercial zoning regulations are enforced. They use the case of France where nation-wide regulations since 1974 stipulate that "... the creation or extension of any new large retail establishment has first to be approved by a regional zoning board composed of store owners, consumer representatives, and regionally elected politicians" (ibid., p. 1371). By exploiting time- and region-specific variation in the approval decisions of these boards, they are able to identify the effect of these decisions on the development of the local retail sector. The authors find that more stringency in entry deterrence by the regional boards hinders job creation in local retail sectors, and that this effect mainly operates through the positive effect entry deterrence has on retailer concentration.

Data availability on aspects of enforcement is still scarce, but one may get a hint of the extent to which local regulations and regulatory stringency vary across local authorities by turning to qualitative data. The Confederation of Swedish Enterprise (CSE) conducts an annual survey of how entrepreneurs in Swedish municipalities perceive the "business climate" of the municipality in which they have their main operations (including headquarters in the case of multi-plant firms). The survey asks a large number of questions spanning from how satisfied entrepreneurs are with the general service local authorities provide to businesses, to their perception of attitudes towards businesses prevailing in local schools.

Two questions in the survey are of particular interest in the context of enforcement and design of local regulations. The first asks entrepreneurs about the attitudes of local public officials towards entrepreneurship. In the second question entrepreneurs are enquired about their view on how the local authority practices and carries out laws and regulations at large, for instance as reflected in the speed and transparency of the administrative processes associated with various types of permits. While these questions are not designed to specifically deal with regulatory stringency, they still provide a reflection of the order of magnitude in the differences that prevail across local authorities. We can certainly expect that regulations are enforced in a more "business-friendly" way in municipalities where a large fraction of local entrepreneurs are satisfied with the attitudes of local public officials (such as administrators at various types of local public agencies) and with the way local authorities apply laws and regulations. The CSE-survey represents the best available information that we have at our disposal to explore these issues. ${ }^{14}$ It has also been used in a number of recent studies to derive measures of business-related social

\footnotetext{
${ }^{14}$ That is not to claim that the CSE-survey is without problems. First, local entrepreneurs may have an incentive not to answer truthfully, either with a negative or a positive bias, depending on whether the local government represents the same political views as the surveyed entrepreneurs. Second, there is a risk that dynamic entrepreneurs that have more contacts with local authorities, for example due to a need to invest in new plants in
} 
capital and to examine their effect on the frequency of startups (Westlund et al. 2014) and private sector growth (Fölster and Peltzman 2010) in Swedish regions.

So how large are then the variations across municipalities with regard to how local entrepreneurs answer the two questions? Figure 5 provides the answer. The vertical axis measures the percentage of the surveyed local entrepreneurs that in 2012 answered "good", "very good" or "excellent" on either question. Municipalities are ranked in ascending order according to the questions regarding attitudes towards entrepreneurship amongst local public officials.

Figure 5 Local entrepreneurs' perceptions of (1) attitudes to entrepreneurship among local public officials and (2) the local authority's application of laws and regulations across Swedish municipalities in 2012.

Percentage of local entrepreneurs that

answer good, very good or excellent

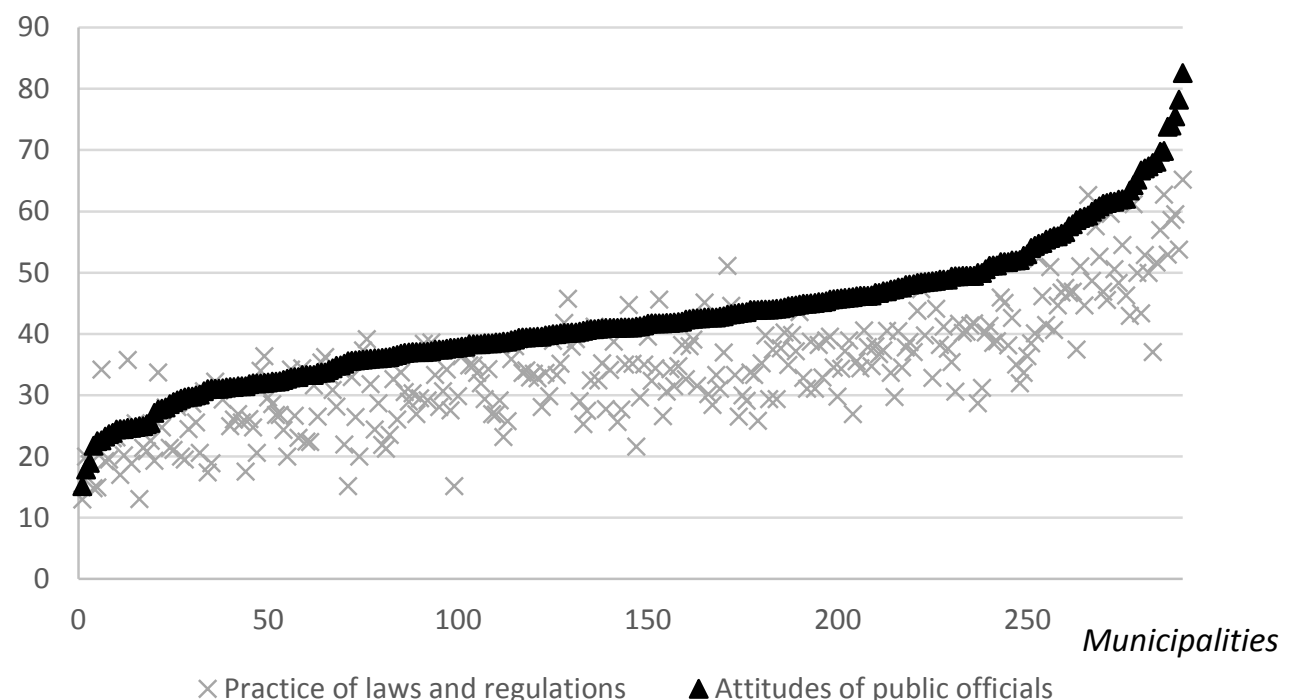

Note: Municipalities ranked in ascending order according to (1).

Source: Confederation of Swedish Enterprise (2012).

The figure sends two main messages. First, there is a rather strong correlation between the two questions. When local entrepreneurs are satisfied with the attitudes of local public officials towards entrepreneurship, they also tend to be satisfied with the way in which local authorities apply and enforce

the municipality, and are therefore more likely to have negative experiences. In short, those who do not need to have contact with local authorities may not experience the 'barriers'. 
laws and regulations. The correlation coefficient between the two series is 0.84 and a simple linear regression shows that perceptions of the attitudes of local public officials towards entrepreneurship can "explain" nearly 70 percent of the variance in the perceptions of how well local authorities apply and enforce laws and regulations.

Second, there are substantial variations in the percentage of surveyed local entrepreneurs that are indeed satisfied with the attitudes and practice of local authorities, i.e., the percentage that answered "good", "very good" or "excellent". It is evident that across municipalities in Sweden, this percentage ranges from just over 10 to about 80 percent. To the extent that these patterns reflect overall differences in the enforcement stringency of regulations, they provide some basis for the claim that there are potentially large overall variations across local authorities in terms of how regulations are designed, applied and enforced.

One reason for these kinds of differences is to be found in the attitudes of the local population at large. It is not a far-fetched conjecture that regions in which the citizens have positive attitudes towards entrepreneurship develop "business-friendly" regulations and enforcement. ${ }^{15}$ This brings us to the role of local informal institutions for entrepreneurship.

\subsection{Informal institutions-local entrepreneurship cultures}

New institutional economists often argue that informal institutions have a long-term influence on the design as well as the implementation of formal institutions. Williamson (2000) stresses that "social embeddedness" is the highest level of institutions and that "...this is where the norms, customs, mores, traditions, etc., are located" (p. 596). Such informal institutions are claimed to change very slowly over time, and impose important constraints on the formal institutional environment (the rules of the game) as well as on governance (the play of the game). This type of dependence on slowly changing informal institutions is at least as important for regions as it is for nations.

Historical and locally embedded "entrepreneurship cultures" where the collective values and norms are positively oriented towards entrepreneurship could certainly be important in fostering a social

\footnotetext{
${ }^{15}$ After all, in democracies voters elect politicians that suggest and implement policies and reforms that voters prefer.
} 
environment conducive for entrepreneurs (cf. Aldrich 1990; Aldrich and Fiol 1994). ${ }^{16}$ The influence of such a culture does not only pertain to issues associated with design and enforcement of local regulations, and attitudes of elected local politicians and bureaucrats. Values and norms have broad effects that permeate many levels of a (local) economy. Etzioni (1987) argues that the extent of entrepreneurial activities and their effects in a society are ultimately a reflection of the extent to which entrepreneurship is legitimized in that society:

The extent to which entrepreneurship is legitimate, the demand for it is higher; the supply of entrepreneurship is higher; and more resources are allocated to the entrepreneurial function. (ibid., p. 175) [......] In the terms used by economists, legitimation is a key factor which affects the preferences, the constraints, and the resource allocation simultaneously. (ibid., p. 185)

If values are an immediate source of legitimation, as Etzioni (1987) maintains, then it follows that an entrepreneurial culture may have a strong influence on entrepreneurship.

There are many different ways in which the effect of a local entrepreneurship culture is materialized and maintained over time. One mechanism runs through role model effects, which may take at least three forms. First, the sheer observation of a high density of entrepreneurs in one's local environment may stimulate entrepreneurial behavior by inducing motivation and self-confidence, e.g., with reference to notions like "if they can do it, I can too" (Sorenson and Audia 2000). Second, in regions with a strong entrepreneurship culture, entrepreneurs have a high social status and this status effect may trigger entrepreneurial endeavors (cf. Casson 1995). Third, a high local density of role model entrepreneurs automatically translates into a high density of people with experience of running businesses, which means in turn that there is a local abundance of information and knowledge about the practice of entrepreneurship. This increases the odds that local inhabitants acquire entrepreneurial skills and

\footnotetext{
${ }^{16}$ There are of course many potential sources of an entrepreneurship culture. Regions with a history of dependence on one or a few large employers, such as mining and shipyard cities, are often argued to have developed a culture of labor rather than entrepreneurs, and associated high rates of historical unionization rates (cf. Glaeser et al. 2012). In the sociological literature, there are arguments that certain religions have historically been less favorable to entrepreneurship than others. Weber (1930) maintained that Protestant ethics favored entrepreneurship and capitalism. Sombart (1911) asserts that the intellectualism and flexibility of Judaism gave the Jews a catalyst role in the development of capitalism, especially as merchant and financiers. Moreover, the literature on social capital typically claims that persistent differences in economic outcomes have deep historical roots. A prime example is Putnam (1993), who maintains that regional differences in trust and cooperation (which influence current economic outcomes) in Italy are strongly related to the historical circumstances, where certain cities experienced independence in the first few centuries of the second millennium.
} 
become entrepreneurs (Guiso and Schivardi 2011). Minniti (2005) further maintains that social interactions with established entrepreneurs in a local milieu will reduce ambiguities and uncertainties about the practice of entrepreneurship and the startup process.

The above mechanisms exemplify how a local entrepreneurship culture, whatever its sources, breed new entrepreneurs, who in turn help sustaining the culture over time. In fact, local social network externalities in entrepreneurship-regardless of whether they have to do with information, knowledge, status-effects or self-confidence-suggest that entrepreneurship is self-reinforcing over time. As Minniti $(2005$, p. 3) puts it: “... entrepreneurship creates a 'culture' of itself that influences individual behavior in its favor."

There are several studies that find robust empirical evidence that regions do have distinct entrepreneurship cultures. One set of evidence comes from analyses of long-term persistence in crossregional variations in entrepreneurship. Fritsch and Wyrwich (2013) show that differences in selfemployment and new firm formation across regions in Germany are not only substantial, but have endured over periods as long as 80 years. They find that the self-employment rate in 1925 in German regions is a highly robust determinant of their entrepreneurial activity in 2005. Since this is a time period covering several disruptive changes in the German economy, they interpret this as reflecting a longlasting influence of slowly changing locally embedded entrepreneurship cultures. ${ }^{17}$ The main intuition behind this inference is straightforward: culture changes slowly, and so should phenomena dependent on it. While most analyses do not cover such a long period of time, persistent variations in entrepreneurship across regions and a strong influence of lagged startup rates on current ones have been documented for several different countries and time periods. ${ }^{18}$

Indirect evidence is also provided by analyses showing that the type of role model effects discussed above is important. Bosma et al. (2012) list three sets of evidence: (i) the decision to become an entrepreneur is positively associated with having entrepreneurs in one's social network (Kim and Aldrich 2005; Klyver et al. 2007); (ii) there is a positive influence of having parents who are (or have been) entrepreneurs (Chlosta et al. 2012; Dunn and Holtz-Eakin 2000); and (iii) entrepreneurial behavior of

\footnotetext{
${ }^{17}$ As explained by the authors, the disruptive changes are massive and include the Great Depression starting in the late 1920s, World War II, occupation by the allied powers, massive in-migration, a new constitutional base and political system, as well as postwar economic reconstruction.

${ }^{18}$ See, e.g., Andersson and Koster (2011) and Andersson (2012) for the case of regions in Sweden and Fotopoulos (2013) for the case of regions in the UK.
} 
school, workplace and neighborhood peers, respectively, influence entrepreneurial behavior (Falck et al. 2012; Nanda and Sorensen 2010; Andersson and Larsson 2013; Giannetti and Simonov 2009). These findings point to the empirical relevance of the arguments of positive effects of local role models for entrepreneurship.

Case studies offer another set of evidence of entrepreneurial regions. One of the most well-known studies in this vein is Saxenian's (1994) analysis of Silicon Valley and Route 128. While both regions had a historically strong concentration of knowledge- and technology-intensive sectors and bright prospects for long-term economic resilience, the regions developed along different trajectories after the crisis period in the early 1980s. Silicon Valley continued to flourish whereas Route 128 declined. Saxenian maintains that one important explanation for the divergent performance of the regions is rooted in differences in entrepreneurship culture. ${ }^{19}$ A Swedish example is the so-called "Gnosjö spirit". While this region is far from Silicon Valley in terms of economic vibrancy and technological sophistication, it is an example of a small remote region that manages to retain high employment rates despite its remoteness from leading metropolitan centers and a traditional manufacturing economic base. Its success in this regard is often claimed to be rooted in a strong entrepreneurship culture referred to as the "Gnosjö spirit" (Johannisson and Wigren 2006). This spirit is even recognized in the Swedish National Encyclopedia, ${ }^{20}$ where it is described as follows (translation by the authors):

The Gnosjö spirit refers to the enterprising culture that prevails in the municipality of Gnosjö and its neighboring municipalities in the county of Småland. In this region, entrepreneurship is a way of life that dominates the local community, which implies, among other things, that the local authorities, banks, and trade unions adjust their practices to the needs and interests of the [local] enterprises.

It should still be recognized that arguments concerning local cultures for entrepreneurship may be criticized on the grounds that they often draw on experiences from regions not characterized by highimpact entrepreneurship, but rather small-scale family-oriented businesses in traditional (low-tech)

\footnotetext{
${ }^{19}$ In an often quoted passage Saxenian (1994) quotes an entrepreneur who moved from Boston to Silicon Valley (p. 63): "In Boston, if I said I was starting a company, people would look at me and say: 'Are you sure you want to take the risk? You are so well established. Why would you give up a good job as vice president at a big company?' In California, I became a folk hero when I decided to start a company. It wasn't just my colleagues. My insurance man, my water deliverer - everyone was excited. It's a different culture out here."

${ }^{20} \mathrm{http} / / /$ www.ne.se/lang/gnosj\%C3\%B6anda
} 
sectors. Many examples of "entrepreneurial districts" discussed in the literature, such as the regions of Bologna and Emilia-Romagna known as the "third Italy" (Piore and Sabel 1984; Becattini 1990) and the Gnosjö region (Johannisson 1984), may indeed be characterized by flexibility, small-scale businesses and self-employment, but rarely by research- or technology-based new firms. The regions in third Italy are known for a specialization in craft-based industries (Boschma 2005). Similarly, the Gnosjö region is known for a specialization in traditional low-tech manufacturing sectors and has, by Swedish standards, a local labor force with a modest level of formal training. These are indeed characteristics not normally associated with Schumpeterian entrepreneurship in the form discussed in Section 2 above. ${ }^{21}$

In this regard, Silicon Valley is an exception. Still, a strong local entrepreneurship culture is certainly only one of many potential explanations for the region's success. Klepper $(2010,2011)$ attributes a large part of the growth of the semi-conductor industry in the region to the establishment of a few large initial firms, notably Fairchild Semiconductor, which subsequently spawned new high-quality firms through spinoff processes. Related to this is the fact that California has institutional arrangements favoring mobility, including spinoffs. In particular, it proscribes so-called non-compete agreements, i.e., agreements stating that an employee leaving a firm is not allowed to enter into or start a similar firm in competition with his/her previous employer. No doubt, the absence of such non-compete clauses may have stimulated spinoff processes and contributed to the region's vibrant entrepreneurship culture (cf. Gilson 1999).

This raises the issue of cultural explanations as proximate or ultimate causes. Klepper's $(2010,2011)$ story suggests that a culture may be more an outcome of a first cohort of entrepreneurs that initiate virtuous self-reinforcing processes of spinoffs, labor mobility and social network externalities. A vivid entrepreneurial culture may not be the cause but rather a by-product of institutions that foster entrepreneurship (Boettke and Coyne 2009). Culture is then a proximate rather than an ultimate cause.

Notwithstanding these critical remarks, there are strong theoretical arguments as well as an empirical research literature suggesting that local entrepreneurship cultures (irrespective of their source) are important in influencing entrepreneurial endeavors in regions, and that they also could influence pertinent formal institutions.

\footnotetext{
${ }^{21}$ What is more, we know of no empirical paper on peer effects and social network externalities that specifically deal with high-impact entrepreneurs. Instead, many of these papers use self-employment as the main indicator of entrepreneurship.
} 
The final question is then to what extent local entrepreneurship cultures could be fostered. We argue that, in general, cultural patterns are not immutable. Public policy can alter social attitudes over time. To the extent that norms and attitudes are culturally codified products of the reward structures in society, institutional changes are likely to affect norms and attitudes (Bowles 1998, Baumol et al. 2007, pp. 203ff; Smith 2003). But such processes may take many years, even decades, to complete. In a recent study, Fritsch et al. (2014) show that after the introduction of a formal institutional framework of a market economy in East Germany, it took about 15 years for the startup rate to reach West German levels. Their findings suggest that informal institutions, such as entrepreneurship cultures, tend to change very slowly and are more persistent than formal ones.

\subsection{A local policy for productive entrepreneurship - what role for the institutional framework?} Having discussed the role played by local formal and informal institutions in fostering local entrepreneurship, we now turn to the role played by the local institutional framework, as defined in Sections 4.2 and 4.3. This is the local analogue to entrepreneurship policy as defined in Figure 1.

Entrepreneurship policy puts individuals rather than firms at center stage. New firms and new ideas are after all developed by individuals, which means that the level of productive entrepreneurship in a locality is fundamentally linked to the local supply of productive entrepreneurs. Going back to the example of Detroit discussed in the introduction, an argument can certainly be made that the city lacked individual productive entrepreneurs capable of pushing the local economy in new directions. In a post on Economix in the New York Times in 2011 entitled "Can Detroit Find the Road Forward?", Edward Glaeser indeed claims that the city of Detroit "...needed the home-grown talent that could have enabled a new generation of entrepreneurs" ${ }^{22}$ This suggests that a key concern for local policy is the local supply of productive entrepreneurs.

As discussed in Section 4.1, one source of the spatial allocation of entrepreneurs (or people with entrepreneurial skills) is spatial sorting. Individuals are truly heterogeneous and differ in many dimensions, such as socio-economic backgrounds, education, and work and occupational experience. Thus, they differ in terms of attributes associated with entrepreneurial skills, at least as assessed by the

\footnotetext{
${ }^{22}$ http://economix.blogs.nytimes.com/2011/02/22/can-detroit-find-the-road-forward.
} 
influence those kinds of attributes have on startup propensities (see, e.g., the transition analyses in Dunn and Holtz-Eakin 2000 and in Andersson and Klepper 2013). ${ }^{23}$ Individuals are also mobile across space, especially within countries. Therefore, differences in entrepreneurship across places could simply be due to differences in the local supply of entrepreneurial people, which in turn may reflect a process of nonrandom spatial sorting of individuals with respect to entrepreneurial skills.

The most recent literature on the sources of spatial disparities in economic outcomes, such as productivity, income and employment, puts great emphasis on spatial sorting by skills. Analyses of spatial wage equations at the worker level, for instance, more often than not find that spatial sorting is the single most important explanation for differences in earnings across regions (Combes et al. 2008; Larsson 2014; Andersson et al. 2014). In other words, the general message is that who you are is much more important than where you live in explaining individual economic outcomes. People with different characteristics and skills make different choices regarding where to live and work.

But what drives sorting of entrepreneurial people to various places? It would certainly be naïve to claim that entrepreneurial individuals are forward-looking and completely informed of the institutional environment in various regions. There certainly exist potential entrepreneurs who, knowing that they at some point in the future would like to start a firm, select where to live and work based on the conditions for entrepreneurship. However, they are likely to be atypical. Our interpretation of the evidence is rather that many productive entrepreneurs, such as founders of high-impact startups, often did not have a long-term plan to become entrepreneurs. The decision to start a firm is to a great extent driven by contextual factors and serendipity, and often occurs after several years of work experience (Shane 2003). It could for instance be a discovery in a research lab, an idea developed while working in an incumbent firm or an everyday life experience that trigger new firm formation. Howard Schultz, president and CEO of Starbucks, is a good example of the latter. At a trip to Italy he became captivated with Italian coffe bars and the coffee experience. This gave him the vision to bring the Italian coffeehouse tradition to the U.S.

\footnotetext{
${ }^{23}$ Lucas' (1978) classic model of entrepreneurship also explains differences in the likelihood of becoming an entrepreneur by the exogenously given "talent for managing", understood as the ability to extract output from a given combination of inputs. While part of entrepreneurial skills of an individual may indeed be truly exogenous ("inherited"), in reality they are in many cases a side-effect of a sequence of decisions about education, work and place of residence. Yet, at a given moment in time entrepreneurial skills may be considered pre-determined by historical decisions and traits.
} 
On the other hand, one could argue that entrepreneurs choose a favorable environment once they have decided to start a firm. Still, although entrepreneurs are often characterized as "foot-loose" in theoretical models (e.g., Pflüger and Südekum 2008), available evidence of the location of startups and entrepreneurs suggest that they tend to start their firm in their "home region" where they are embedded and have social networks (Dahl and Sorenson 2009, 2012; Figueiredo et al. 2002). ${ }^{24}$ The default location choice of startups is typically to remain in the region where the entrepreneur already lives and works. This suggest that spatial sorting of entrepreneurial people may in many cases be due to reasons not directly related to the startup process or (pre-determined) intentions to start a firm.

Spatial sorting of individuals with entrepreneurial skills is instead likely to occur in much the same way as it does for individuals in general-i.e., as a result of factors such as availability of affordable housing, pleasant living conditions, quality of local public services and labor market prospects. What may be particularly important for entrepreneurial individuals, however, is the thickness of the market(s) for skills. As the discussion of billionaire entrepreneurs in Section 2 suggests, individuals with a potential to become productive entrepreneurs by founding firms that usher in new technologies and radical change are often well educated with advanced degrees from elite universities. The location choice of talented, ambitious and entrepreneurial graduates is often governed by career prospects and the long-term expected returns on their human capital.

A recent analysis of graduates in Sweden by Ahlin et al. (2014) shows that nearly two thirds of graduates in natural sciences, engineering and social sciences in Sweden choose to start their labor market career in one of the country's three largest cities. They also find that the propensity to move to a large city upon graduation is significantly higher for graduates with greater abilities (or motivation). ${ }^{25}$ The big cities offer thicker markets for skills and more jobs and occupations where skilled and motivated graduates can exploit their abilities in full. ${ }^{26}$ In economic geography, the term "escalator region" is sometimes used to describe regions that are attractive to young educated talents (Fielding 1992). These regions offer superior prospects for returns to their abilities and educational investments in terms of progression from

\footnotetext{
${ }^{24}$ There are various explanations for this pattern: Attachment to family and friends, local social networks implying access to resources, ties to former colleagues which provide better access to potential employees etc. There is also evidence that firms started "at home" actually perform better than other firms (Dahl and Sorenson 2012; Carias and Klepper 2010).

${ }^{25}$ High-school grades and the education-level of the graduates' parents are used as proxies for latent abilities.

${ }^{26}$ Ahlin et al. (2014) find that graduates moving to the large cities have higher employment rates, higher initial wages and experience more rapid wage growth in their first eight years on the labor market. Moreover, the faster wage growth is coupled with a higher rate of inter-firm job-switching.
} 
education into advanced jobs and churning between professional and managerial occupations. Fielding (1992) portrays the South-East region of England (notably the London region) as an "upward escalator" within the British urban and regional system. ${ }^{27}$

While it is natural think of big cities, such as London, New York and Paris, as escalator regions, smaller cities and clusters can also be characterized as escalators within specific areas of expertise. In fact, the local presence of an entrepreneurial and innovation-driven firm may be a decisive factor in attracting talents. At the time when Microsoft moved their headquarters from Albuquerque to Seattle, for example, Seattle was not known as a city with good labor market prospects for skilled programmers and IT professionals (Moretti 2012). After Microsoft entered the city, it became more attractive as a place of residence for entrepreneurial talents in IT and related areas. Similarly, there is no doubt that the high density of entrepreneurial high-tech firms in Silicon Valley, not least Google, is important in attracting (and retaining) computer and programming talents to the region. Moreover, for small cities and regions far from the size and stature of Seattle or Silicon Valley, the local presence of an establishment of a multinational corporation can make a big difference for the ability to retain and attract talents. Despite the small size of the city or region, individuals can make a career through the "internal" labor market within the corporation. That is, the internal career opportunities within a multinational (including facilities abroad) could, from the viewpoint of individuals, "substitute" for a thick regional labor market for skills. ${ }^{28}$

The above arguments suggest that the spatial allocation of entrepreneurial talent is a function of the spatial distribution of entrepreneurial incumbent firms. ${ }^{29}$ This view is also consistent with the evidence of the role the existing stock of firms in a region plays for the emergence of new local high-impact firms.

\footnotetext{
${ }^{27}$ The special role of the London region in England in attracting young talents was already recognized by Alfred Marshall. Referring to London's attractiveness as place of residence for the "best blood in England" he further wrote: "... the most enterprising, the most highly gifted, those with the highest physique and the strongest characters go there to find scope for their abilities" (Marshall 1890).

${ }^{28}$ In a survey of 2,000 highly educated people belonging to Swedish career network 4Potentials, it is shown that job opportunities, availability of more qualified positions within firms and the possibility of working internationally are primary reasons for location decisions (4Potentials 2012).

${ }^{29}$ An objection to this line of reasoning may be that there is interdependence between the spatial sorting of entrepreneurial firms and individuals - i.e., "good" firms choose locations where there are many 'good' employees and vice versa. While this is certainly true at the aggregate level, the location of incumbent firms is truly exogenous from the viewpoint of an individual's decision of where to live and work. The location choice of a single individual typically has no effect on the location choice of firms. Yet, the location choice of a single entrepreneurial firm may have an influence on the location choice of several individuals seeking a job.
} 
Despite the high variance in post-entry survival and growth of new firms (Mata et al. 1995), there is robust evidence in the literature that incumbent firms are important sources for new productive (highimpact) entrepreneurs. In a well-known study, Bhidé (1994) surveyed the "Inc. 500" fastest growing private firms and found that 71 percent had replicated or modified an idea encountered through previous employment. Several studies confirm that spinoffs in the form of employee startups are a particular class of entrants with lower hazards and stronger employment growth (e.g., Andersson and Klepper 2013 and Eriksson and Kuhn 2006). Spinoffs are also shown to have played an important role in the historical evolution in many industries (U.S. automobile industry, Klepper 2002; laser industry, Klepper and Sleeper 2005; semiconductors, Malone 1985; disk drive industry, Agarwal et al. 2004).

There is also evidence that some types of incumbent firms are more likely to spawn spinoffs than others. Klepper (2001) reviews the evidence of spinoffs and conclude that entrepreneurial and innovative incumbents appear to be more inclined to spawn new firms. The Klepper and Sleeper (2005) study of the U.S. laser industry, for example, shows that spinoff rates fall as the industry matures and knowledge becomes more embodied in physical rather than human capital. Moreover, Andersson and Klepper (2013) find that multinationals are somewhat less likely to spawn new firms, but that the firms they spawn have higher post-entry survival rates. They interpret this as suggesting that founders of spinoffs from multinationals are of higher quality. This may in turn be explained by employees at multinationals having acquired a greater range of valuable experiences and knowledge. Multinationals typically have large R\&D budgets and more intangible assets (Markusen 1995), which gives entrepreneurially talented employees good opportunities to acquire largely tacit knowledge, which is more difficult to acquire elsewhere.

These patterns are often explained by organizational heredity, i.e., spinoffs inherit knowledge and capabilities from their parent firms which boost their performance. But it can also reflect that entrepreneurial incumbents are better at attracting talented and entrepreneurial employees, who are alert to entrepreneurial opportunities and new ideas upon which a spinoff could be based.

In summary, we have emphasized that one way in which potentially productive entrepreneurs (with supposedly higher propensity to found new high-impact firms) sort in space is by being attracted to regions offering thick markets for skills and/or many employment opportunities in entrepreneurial and innovative incumbent firms. When making their location choices these people may not have weighed in 
any intention of becoming an entrepreneur in the future. Instead, these individuals acquire experience and get ideas as employees in the incumbents, and may at a later stage choose to leave their employer and start a spinoff. There is indeed substantial empirical support for the argument that "incumbent firms are natural training grounds for the next generation of entrepreneurs" (Klepper 2011, p. 145) and that "the breeding grounds for entrepreneurial firms are more likely to be other entrepreneurial firms" (Gompers et al. 2005, p. 612). ${ }^{30}$ Spinoffs, in turn, typically locate in the same regions as the parent firms.

To illustrate the empirical relevance of the latter phenomenon, Table 4 presents data on the fraction (in percent) of spinoffs in Sweden during the period 1993-2005 that locate in the same municipality and region as the parent firm. The original data come from Andersson and Klepper (2013) and are based on 15,103 spinoffs with two or more initial employees.

Table 4 Fraction of spinoffs locating in the same municipality or region as the parent firm.

\begin{tabular}{l|c}
\hline $\begin{array}{l}\text { Same municipality as parent } \\
\text { firm }\end{array}$ & $72 \%$ \\
$\begin{array}{l}\text { Same region but not same } \\
\text { municipality }\end{array}$ & $16 \%$ \\
Sum & $88 \%$ \\
\hline
\end{tabular}

Source: Andersson and Klepper (2013).

The table shows that 72 percent of the spinoffs during the period located in the same municipality as the parent firm, and another 16 percent remained in the same labor market region although not in the same municipality. Thus, 88 percent of the spinoffs located in the same "home region" as the parent firm. This supports the view that a high rate of spinoffs in a region is strongly linked to the local presence of incumbents that spawn new firms, and illustrates the significant effects the local presence of entrepreneurial incumbents is likely to have on the level of productive entrepreneurship in a region.

\footnotetext{
${ }^{30}$ This view seems to also be shared by industry professionals. For example, Gordon Moore, the founder of Intel and known for "Moore's Law", has stated that "... successful startups almost always begin with an idea that has ripened in the research organization of a large company (or university). Any region without larger companies at the technology frontier or research organizations of large companies will probably have fewer companies starting or spinning off" (as quoted in Auerswald and Branscomb 2003, p. 236).
} 
Given our discussion of underlying drivers of the local supply of entrepreneurs, the natural question concerns our conclusions for policy and, in particular, the role played by the type of local institutions discussed in sections 4.2 and 4.3 .

A general message from the perspective presented here is that local policy must recognize the interaction between existing businesses and individual location choices in shaping the geography of productive entrepreneurship. Talented people-including latent entrepreneurs-will flow to regions with an innovative and vibrant business sector. Likewise, innovative industries may be drawn to places with good access to a large pool of talented workers. A narrow view focusing either on firms or individuals will miss pertinent policy measures. While our emphasis on entrepreneurial individuals linked back to firms through the argument that they value market thickness and the prospects for returns on their abilities, we also underlined that they are likely to look for what people in general look for: Affordable housing, pleasant living conditions, local public services of high quality and favorable labor market prospects. Local policy does best in being two-pronged and consider both firms and individuals, i.e., the climate both for businesses and for people.

Our review and assessment of the various ways in which local formal and informal institutions influence entrepreneurship also make clear that the local institutional framework is important in influencing the local supply of potential productive entrepreneurs as well as spinoff processes. An obvious influence runs through the effect of the local institutional environment on the location of entrepreneurial incumbents. The extant research literature on the effect of local taxes and regulations (including stringency of enforcement) on local businesses suggests that they influence both the frequency of startups and the location decisions of incumbents. Unfavorable taxes and regulations certainly repel not only business activity in general, but also entrepreneurial incumbents that are potential sources of spinoffs and attractors of talented employees.

Still, favorable local entrepreneurship policies not only increases the odds that a region develops or manage to attract entrepreneurial incumbents, but also the odds that a region reaps the full potential of having an entrepreneurial incumbent in a region. Consider a decision by an innovative firm to move into a region or the sudden start of a new truly Schumpeterian innovative firm in a region. Such events may 
or may not be due to the local institutional framework. ${ }^{31}$ Regardless of what triggered the event, it entails a significant potential for further regional development thanks to considerable multiplier effects. A well-designed entrepreneurship policy may stimulate the development of a local supply of supporting business services, input suppliers and variety of consumer services sectors, i.e., local factors that are likely to be important in attracting additional productive entrepreneurs and entrepreneurial firms. In short, a process of cumulative growth that often characterizes local development may be initiated (cf. Myrdal 1957).

We argue that the local institutional environment is important in enabling and materializing these potential effects. Multiplier effects of the type described above are at least in part materialized in the form of local entrepreneurs acting on the new opportunities. It is reasonable to conclude that the local response to these opportunities depends on local regulations and other types of formal as well as informal barriers to entrepreneurship. For example, an entrepreneurial incumbent firm may need to expand its operations as it attracts employees, and the ease by which such expansion is undertaken will depend at least in part on land-use restrictions. New employees in a region may demand attractive housing, the supply of which is influenced by residential zoning regulations. Furthermore, additional well-paid jobs in a region create demand for local everyday services such as hairdressers and restaurants (Moretti and Thulin 2013). Realization of these kinds of businesses also requires people who act on the new entrepreneurial opportunities (which may be conditioned by the local entrepreneurship culture) as well as enabling zoning regulations for retailing and other sectors. Greater variety in consumer services may in turn make the city more attractive for people valuing "consumer cities" (Glaeser et al. 2001). Likewise, the development of ancillary producer services sectors and a local "ecosystem" of supporting competence structures require entrepreneurs acting on those business opportunities.

All of the effects discussed above are positive in the sense that they feed-back on the local economy. Once realized, they further enhance the regions' attractiveness for entrepreneurial firms as well as for individuals. It is clear that the formal as well as informal institutional framework conditions could facilitate or constrain. Local policymakers have much to gain from actively working on improving the

\footnotetext{
${ }^{31}$ One event that appears to primarily have been due to serendipity is Microsoft's decision to move from Albuquerque to Seattle in the late 1970s. Arguably this decision had little to do with returns to entrepreneurship, taxes, local labor pools or any of the standard factors discussed in the literature on business location (Moretti 2012). Seattle just happened to be Bill Gates' hometown. Nevertheless, this decision turned out to be crucial for the development of Seattle.
} 
formal as well as informal institutional framework conditions. A favorable local institutional environment not only increases the odds that strategically important firms develop or move into the region; it also increases the "readiness" to exploit the potential associated with hosting entrepreneurial and knowledge-intensive activities.

\section{Summary and concluding remarks}

We have reviewed and assessed the role local institutional framework conditions play in fostering local entrepreneurship. While local institutions always evolve and operate against the backdrop of the national institutional framework, in particular in non-federal states, we have argued that there is plenty of room for local initiatives and policies to influence the entrepreneurial climate locally. This pertains to both formal (e.g., taxes, regulations and stringency of enforcement) and informal (e.g., attitudes and social legitimacy) institutions. We also argued that the local institutional environment is essential in any local policy aimed at promoting high-impact entrepreneurship. The reason is that favorable local institutions not only increase the odds that a region develops or manage to attract entrepreneurial firms and individuals, but also the odds that a region reaps the full potential of hosting entrepreneurial and knowledge-intensive activities.

There are many ways in which policymakers could to improve the local institutional framework conditions. These include measures to reduce the regulatory burden and streamline administrative processes pertaining to businesses. Local regulations governing businesses should be efficient and transparent. They also comprise local taxes, housing regulations, zoning laws and the overall quality of public services, notably healthcare and schools.

It should be recognized that policies addressing the institutional setup are of a horizontal nature, meaning that they pertain to the overall local conditions that affect industry and individuals (cf. Nathan and Overman 2013 and Duranton 2011). Our discussion of policy does not focus on a specific type of high-impact entrepreneurship policy per se. Instead, we argue that the prospects of high-impact entrepreneurship is very much linked to the general institutional framework conditions of a locality, because it determines the overall attractiveness for both incumbent (entrepreneurial) firms and skilled workers, i.e., latent entrepreneurs. In view of this we hold that local policy does best in being twopronged, considering both firms and individuals, i.e., the climate both for businesses and for people. 
Vertical place-based policies, i.e., policies focusing on attracting certain sectors or firms to a region, may be warranted in circumstances when targeted activities have proven to have a potential to generate local spillover effects (Glaeser 2001). For example, if certain establishments offer agglomeration economies, then it may motivate location-based tax incentives to such establishments because their local presence could imply a self-reinforcing positive effect which benefits local residents and firms (cf. Greenstone et al. 2010). However, even if a vertical policy is successful in the sense that, say, a high-tech industry establishes itself in a region, we argue that the magnitude of spillover effects in terms of spinoffs, growth of supporting businesses and inflow of skilled workers is fundamentally linked to the institutional environment. The odds that such spillover effects are realized depend on the local "readiness", and this readiness is manifested in general local conditions such as tax codes, regulations, housing policies, zoning laws and the overall quality of public services. A vertical policy which targets certain entrepreneurial activities with potentially high-impact is thus unlikely to be worthwhile unless sound horizontal policies are in place. At the same time, vertical policies are subject to the challenge of targeting the right activities.

Our review has also indicated a number of areas for further research. First, most studies focus on the effects of the local milieu on the frequency of entrepreneurship, typically measured startup rates of new firms, establishments or crude measures like the self-employment rate. There is a need to explicitly study the link between the local institutional setup and the nature and direction of entrepreneurship, and consider broader measures of entrepreneurship, such as investments and expansion and diversification of entrepreneurial incumbent firms. Empirical analyses should recognize to a greater extent that entrepreneurship in the Schumpeterian sense cannot be equated with small businesses and selfemployment and critically discuss what typical proxies can and cannot capture.

Second, there is a need to further analyze the relationship between local institutions and the supply of entrepreneurship. One particular question in this regard concerns the empirical relevance of spatial sorting, i.e., the extent to which people with entrepreneurial intentions or abilities (or incumbent firms with intentions to expand) sort themselves to regions with institutional setups favoring productive entrepreneurship. While we conjectured that such a sorting is likely to be important and to occur in interaction between individuals and the existing business structure, there is a dearth of studies that explicitly analyze the extent and nature of sorting of entrepreneurial skills across regions. 
Third, the literature on the role of local informal institutions is much larger than the literature on the role of local regulatory frameworks. While this may in part reflect that data on regulations at the local level is difficult to find, it is still an important area of research with potentially significant policy implications for local governments. One intriguing aspect concerns the interaction between formal and informal local institutions.

Finally, our arguments regarding the role the local institutional framework for productive entrepreneurship also suggest that the magnitude of local multipliers and growth effects associated with the local presence of entrepreneurial and knowledge-intensive activities are a function of the local institutional environment. This is a hypothesis that remains to be rigorously tested in empirical work. 


\section{References}

4Potentials (2012), "Att behålla och utveckla talanger - en studie genomförd hösten 2011 i talangnätverket 4Potentials", Report at 4Potentials

Acemoglu, Daron, and Simon Johnson (2005), "Unbundling Institutions." Journal of Political Economy 113(5), 947-997.

Acs, Zoltan J. (2008), "Foundations of High Impact Entrepreneurship." Foundations and Trends in Entrepreneurship 4(6), 535-620.

Acs, Zoltan J., and Laszlo Szerb (2007), "Entrepreneurship, Economic Growth and Public Policy." Small Business Economics 28(2-3), 109-122.

Acs, Zoltan J., Edward L. Glaeser, Robert E. Litan, Lee Fleming, Stephan J. Goetz, William R. Kerr, Steven Klepper, Stuart S. Rosenthal, Olav Sorenson and William C. Strange (2008), "Entrepreneurship and Urban Success: Toward a Policy Consensus." Economics Faculty Scholarship, Paper No. 61, Syracuse University. Available online: http://surface.syr.edu/ecn/61 (accessed January 20, 2014).

Agarwal, Rajshree, Raj Echambadi, April M. Franco and M. B. Sarkar (2004), “Knowledge Transfer through Inheritance: Spinout Generation, Development, and Survival." Academy of Management Journal 47(4), 501-522.

Aghion, Philippe, Richard Blundell, Rachel Griffith, Peter Howitt and Susanne Prantl (2009), "The Effects of Entry on Incumbent Innovation and Productivity." Quarterly Journal of Economics 91(1), 20-32.

Aghion, Philippe, Richard Blundell, Rachel Griffith, Peter Howitt and Susanne Prantl (2004), “Entry and Productivity Growth: Evidence from Microlevel Panel Data", Journal of the European Economic Association 2(2-3), 265-276.

Aghion, Philippe, Yann Algan, Pierre Cahuc and Andrei Shleifer (2010), "Regulation and Distrust." Quarterly Journal of Economics 125(3), 1015-1049.

Ahlin, Lina, Martin Andersson and Per Thulin (2014), "Market Thickness and the Early Labor Market Career of University Graduates: An Urban Advantage?" Spatial Economic Analysis, forthcoming.

Aldrich, Howard E. (1990), "Using an Ecological Perspective to Study Organization Founding Rates." Entrepreneurship Theory and Practice 4(3), 7-24.

Aldrich, Howard E., and Marlene C. Fiol (1994), "Fools Rush in? The Institutional Context of Industry Creation." Academy of Management Review 19(4), 645-670.

Andersen, Torben M. (2005), "The Danish Labor Market-from Excess to Shortage." In Martin Werding, ed., Structural Unemployment in Western Europe: Reasons and Remedies. Cambridge MA: MIT Press. 
Andersson, Martin (2012), "Startup Rates, Entrepreneurship Culture and the Business Cycle." In Pontus Braunerhjelm, ed., Entrepreneurship, Norms and the Business Cycle: The Swedish Economic Forum Report 2012. Stockholm: Swedish Economic Forum.

Andersson, Martin, and Johan P. Larsson (2013), "Local Clusters of Entrepreneurs: Neighborhood PeerEffects in Entrepreneurship?" CIRCLE Electronic Working Papers No. 213/30, Lund University.

Andersson, Martin, and Sierdjan Koster (2011), "Source of Persistence in Regional Startup Rates: Evidence from Sweden." Journal of Economic Geography 11(1), 179-201.

Andersson, Martin, and Steven Klepper (2013), "Characteristics and Performance of New Firms and Spinoffs in Sweden." Industrial and Corporate Change 22(1), 245-280.

Andersson, Martin, Pontus Braunerhjelm and Per Thulin (2012), "Creative Destruction: Entrepreneurship by Type, Sector and Sequence." Journal of Entrepreneurship and Public Policy 1(2), 125-146.

Andersson, Martin, Johan Klaesson and Johan P. Larsson (2014), "The Sources of the Urban Wage Premium by Worker Skills: Spatial Sorting or Agglomeration Economies?" Papers in Regional Science, DOI: $10.1111 /$ pirs.12025

Armington, Catherine, and Zoltan J. Acs (2002), "The Determinants of Regional Variation in New Firm Formation." Regional Studies 36(1), 33-45.

Audretsch, David B. (2002), "The Dynamic Role of Small Firms: Evidence from the U.S." Small Business Economics 18(1), 13-40.

Audretsch, David B., A. Roy Thurik, Ingrid Verheul and Sander Wennekers. eds. (2002), Entrepreneurship: Determinants and Policy in a European-U.S. Comparison. Boston, Dodrecht and London: Kluwer.

Audretsch, David B., and Michael Fritsch (1994), "The Geography of Firm Births in Germany." Regional Studies 28(4), 359-365.

Audretsch, David B., Isabel Grilo and A. Roy Thurik (2007), "Explaining Entrepreneurship and the Role of Policy: A Framework." In David B. Audretsch, Isabel Grilo and A. Roy Thurik, eds., Handbook of Entrepreneurship Policy. Cheltenham, UK and Northamptom, MA: Edward Elgar.

Audretsch, David B., Isabel Grilo and A. Roy Thurik eds. (2007), Handbook of Entrepreneurship Policy. Cheltenham, UK and Northamptom, MA: Edward Elgar.

Auerswald, Philip E., and Lewis M. Branscomb (2003), "Valleys of Death and Darwinian Seas: Financing the Invention to Innovation in the United States." Journal of Technology Transfer 28(2), 227-239.

Baumol, Willam J. (1990), “Entrepreneurship: Productive, Unproductive, Destructive.” Journal of Political Economy 98(5), 893-921. 
Baumol, William J. (2002), The Free-Market Innovation Machine. Princeton and Oxford: Princeton University Press.

Baumol, William J., Robert E. Litan and Carl J. Schramm (2007), Good Capitalism, Bad Capitalism, and the Economics of Growth and Prosperity. New Haven and London: Yale University Press.

Becattini, Giacomo (1990), "Italy." In Werner Sengenberger, Gary W. Loveman and Michael J. Piore, eds., The Re-Emergence of Small Enterprises: Industrial Restructuring in Industrialised Countries. Geneva: International Labour Organisation.

Bertrand, Marianne and Francis Kramarz (2002), "Does Entry Regulation Hinder Job Creation? Evidence from the French Retail Industry." Quarterly Journal of Economics, 117(4), 1369-1413.

Besley, Timothy, and Maitreesh Ghatak (2010), "Property Rights and Economic Development." In Dani Rodrik och Mark R. Rosenzweig, eds., Handbook of Development Economics, Vol. 5 (pp. 4525-4595). Amsterdam: North-Holland.

Beugelsdijk, Sjoerd (2007), "Entrepreneurial Culture, Regional Innovativeness and Economic Growth." Journal of Evolutionary Economics 17(1), 187-210.

Bhidé, Amar (1994), "How Entrepreneurs Craft Strategies that Work." Harvard Business Review 72(2), 150-161.

Boettke, Peter J., and Christopher J. Coyne (2009), "Context Matters: Institutions and Entrepreneurship." Foundations and Trends in Entrepreneurship 5(3), 135-209.

Boschma, Ron A. (2005), "Social Capital and Regional Development: An Empirical Analysis of the Third Italy." In Ron A. Boschma and Robert C. Kloosterman, eds., Learning from Clusters: A Critical Assessment from Economic-Geographical Perspectives. Berlin: Springer.

Bosma, Niels, Jolanda Hessels, Veronique Schutjens, Mirjam van Praag and Ingrid Verheul (2012), “Entrepreneurship and Role Models." Journal of Economic Psychology 33(2), 410-424.

Bowles, Samuel (1998), "Endogenous Preferences: The Cultural Consequences of Markets and Other Economic Institutions." Journal of Economic Literature 36(1), 75-111.

Braguinsky Serguey, Lee G. Branstetter and André Regateiro (2011), "The Incredible Shrinking Portuguese Firm." NBER Working Paper No. 17265. Cambridge, MA: National Bureau of Economic Research.

Braunerhjelm, Pontus, and Johan E. Eklund (2014), "Taxes, Tax Administrative Burdens and New Firm Formation." Kyklos 67(1), 1-11.

Braunerhjelm, Pontus, Zoltan J. Acs, David B. Audretsch and Bo Carlsson (2010), "The Missing Link: Knowledge Diffusion and Entrepreneurship in Endogenous Growth." Small Business Economics 34(2), $105-125$. 
Bureau of Labor Statistics (2008), Current Population Survey 2008. Available at: http://www.census.gov/cps/.

Caballero, Ricardo (2007), Specificity and the Macroeconomics of Restructuring. Cambridge, MA: MIT Press.

Carias, Cristina, and Steven Klepper (2010), "Entrepreneurship, the Initial Labor Force and the Location of New Firms." Paper presented at the International Schumpeter Society Conference 2010 on Innovation, Organization, Sustainability and Crises, Aalborg Denmark, June 21-24, 2010.

Casson, Mark C. (2003), The Entrepreneur. An Economic Theory. $2^{\text {nd }}$ revised edition. Cheltenham, UK and Northamptom, MA: Edward Elgar.

Casson, Mark C. (1995), Entrepreneurship and Business Culture, Aldershot, UK and Brookfield, MA: Edward Elgar.

Chetty, Raj, John N. Friedman, Tore Olsen and Luigi Pistaferri (2011), “Adjustment Costs, Firm Responses, and Micro vs. Macro Labor Supply Elasticities: Evidence from Danish Tax Records." Quarterly Journal of Economics 126(2), 749-804.

Chlosta, Simone, Holger Patzelt, Sabine B. Klein and Christian Dormann (2012), "Parental Role Models and the Decision to Become Self-Employed: The Moderating Effect of Personality." Small Business Economics 38(1), 121-138.

Cohen, Wesley M. (2005), "Patents and Appropriation: Concerns and Evidence." Journal of Technology Transfer 30(1-2), 57-71.

Combes, Pierre-Philipe, Gilles Duranton and Laurent Gobillon (2008), "Spatial Wage Disparities: Sorting Matters!" Journal of Urban Economics 63(2), 723-742.

Confederation of Swedish Enterprise (2012), http://www.foretagsklimat.se. Stockholm.

Da Rin, Marco, Marina Di Giacomo and Alessandro Sembenelli (2011), "Entrepreneurship, Firm Entry and the Taxation of Corporate Income: Evidence from Europe." Journal of Public Economics 95(9-10), 1048-1066.

Dahl, Michael S., and Olav Sorenson (2009), "The Embedded Entrepreneur." European Management Review 6(3), 172-181.

Dahl, Michael S., and Olav Sorenson (2012), "Home Sweet Home: Entrepreneurs' Location Choices and the Performance of Their Ventures." Management Science 58(6), 1059-1071.

Daunfeldt, Sven-Olov, Niklas Elert and Niklas Rudholm (2013), "Startups and Firm In-Migration: Evidence from the Swedish Wholesale Industry." Annals of Regional Science 51(2), 471-494. 
Davis, Steven J., John Haltiwanger and Ron Jarmin (2008), "Young Businesses, Economic Churning, and Productivity Gains." Kaufman Foundation Research Series: Turmoil and Growth. Kansas City, MO: Ewing Marion Kauffman Foundation.

Dicken, Peter (2003), Global Shift: Reshaping the Global Economic Map in the $21^{\text {st }}$ Century. London, UK and Thousands Oaks, CA: SAGE Publications.

Djankov, Simeon, Tim Ganser, Caralee McLiesh, Rita Ramalho and Andrei Shleifer (2010), "The Effect of Corporate Taxes on Investment and Entrepreneurship." American Economic Journal: Macroeconomics 2(1), 31-64.

Dunn, Thomas A., and Douglas J. Holtz-Eakin (2000), "Financial Capital, Human Capital, and the Transition to Self-Employment: Evidence from Intergenerational Links." Journal of Labor Economics 18(2), 282305

Duranton, Gilles (2011), “California Dreamin': The Feeble Case for Cluster Policies." Review of Economic Analysis 3(1), 3-45.

Edmark, Karin, and Roger H. Gordon (2013), "The Choice of Organizational Form by Closely-Held Firms in Sweden: Tax versus Non-Tax Determinants." Industrial and Corporate Change 22(1), 219-243.

Eriksson, Tor, and Johan Moritz Kuhn (2006), “Firm Spinoffs in Denmark 1981-2000: Patterns of Entry and Exit." International Journal of Industrial Organization 24(5), 1021-1040.

Etzioni, Amitai (1987), “Entrepreneurship, Adaption and Legitimation: A Macro-Behavioral Perspective.” Journal of Economic Behavior and Organization 8(2), 175-189.

Falck, Oliver, Stephan Heblich and Erik Luedemann (2012), "Identity and Entrepreneurship: Do School Peers Shape Entrepreneurial Intentions?" Small Business Economics 39(1), 39-59.

Fielding, Tony (1992), "Migration and Social Mobility: South East England as an Escalator Region." Regional Studies 26(1), 1-15.

Figueiredo, Octavio, Paulo Guimaraes and Douglas Woodward (2002), "Home-Field Advantage: Location Decisions of Portuguese Entrepreneurs." Journal of Urban Economics 52(1), 341-361.

Fölster, Stefan, and Sam Peltzman (2010), "Competition, Regulation and the Role of Local Government Policies in Swedish Markets." In Richard B. Freeman, Birgitta Swedenborg and Robert, Topel, eds., Reforming the Welfare State: Recovery and Beyond in Sweden (pp. 253-284). Chicago, IL: University of Chicago Press.

Fotopoulos, Georgious (2013), "On the Spatial Stickiness of UK New Firm Formation Rates." Journal of Economic Geography, forthcoming (doi: 10.1093/jeg/lbt011). 
Fritsch, Michael, Elisabeth Bublitz, Alina Sorgner and Michal Wyrwich (2014), "How Much of a Socialist Legacy? The Re-Emergence of Entrepreneurship in the East German Transformation to a Market Economy." Small Business Economics, forthcoming (DOI 10.1007/s11187-014-9544-x).

Fritsch, Michael, and Florian Noseleit (2013), "Investigating the Anatomy of the Employment Effect of New Business Formation." Cambridge Journal of Economics 37(2), 349-377.

Fritsch, Michael, and Pamela Mueller (2004), "Effects of New Business Formation on Regional Development over Time." Regional Studies 38(8), 961-975.

Fritsch, Michael, and Michael Wyrwich (2012), "The Role of a Regional Entrepreneurship Culture: Evidence and Consequences." In Pontus Braunerhjelm, ed., Entrepreneurship, Norms and the Business Cycle: The Swedish Economic Forum Report 2012. Stockholm: Swedish Economic Forum.

Fritsch, Michael, and Michael Wyrwich (2013), "The Long Persistence of Regional Levels of Entrepreneurship: Germany, 1925-2005." Regional Studies, forthcoming (http://dx.doi.org/10.1080/00343404.2013.816414).

Gans, Joshua S., and Lars Persson (2013), "Entrepreneurial Commercialization Choices and the Interaction between IPR and Competition Policy." Industrial and Corporate Change 22(1), 131-151.

Garicano, Luis, Claire Lelarge and John Van Reenen (2013), "Firm Size Distortions and the Productivity Distribution: Evidence from France." CEPR Discussion Paper No. 9495. London: Centre for Economic Policy Research.

Giannetti, Mariassunta, and Andrei Simonov, (2009), "Social Interactions and Entrepreneurial Activity." Journal of Economics \& Management Strategy 18(3), 665-709.

Gilson, Ronald J. (1999), "The Legal Infrastructure of High-Technology Districts: Silicon Valley, Route 128 and Covenants not to Compete." New York University Law Review 74(3), 575-629.

Glaeser, Edward L. (2001), "The Economics of Location Based Tax Incentives." Harvard Institute of Economic Research Discussion Paper 1932. Cambridge, MA: Harvard University.

Glaeser, Edward L. (2007), "Entrepreneurship and the City." NBER Working Paper No. 13551. Cambridge, MA: National Bureau of Economic Research.

Glaeser, Edward L. (2011), "Can Detroit Find the Road Forward?" New York Times, Economix blog, February 22.

Glaeser, Edward L., Sari Pekkala Kerr and William R. Kerr (2012), “Entrepreneurship and Urban Growth: an empirical assessment with historical mines." NBER Working Paper No. 18333. Cambridge, MA: National Bureau of Economic Research. 
Glaeser, Edward L., Jed Kolko and Albert Saiz (2001), "Consumer City." Journal of Economic Geography 1(1), 27-50.

Gompers, Paul A., and Josh Lerner (2001), The Money of Invention: How Venture Capital Creates New Wealth. Cambridge, MA: Harvard University Press.

Gompers, Paul A., Josh Lerner and David Scharfstein (2005), "Entrepreneurial Spawning: Public Corporations and the Genesis of New Ventures, 1986-1999." Journal of Finance 60(2), 557-615.

Greenstone, Michael, Richard Hornbeck and Enrico Moretti (2010), “Identifying Agglomeration Spillovers: Evidence from Winners and Losers of Large Plant Openings." Journal of Political Economy 118(3), $536-598$.

Guiso, Luigi, and Fabiano Schivardi (2011), "What Determines Entrepreneurial Clusters?" Journal of the European Economic Association 9(1), 61-86.

Haltiwanger, John, Ron S. Jarmin and Javier Miranda (2013), "Who Creates Jobs? Small versus Large versus Young." Review of Economics and Statistics 95(2), 347-361.

Haughwout, Andrew, Robert Inman, Steven Craig and Thomas Luce (2004), "Local Revenue Hills: Evidence from Four U.S. Cities." Review of Economics and Statistics 86(2), 570-585.

Hébert, Robert F., and Albert N. Link (2006a), "The Entrepreneur as Innovator." Journal of Technology Transfer 31(5), 589-597.

Hébert, Robert F., and Albert N. Link (2006b), "Historical Perspectives on the Entrepreneur." Foundations and Trends in Entrepreneurship 2(4), 261-408.

Henrekson, Magnus, and Dan Johansson (2009), "Competencies and Institutions Fostering High-Growth Firms." Foundations and Trends in Entrepreneurship 5(1), 1-80.

Henrekson, Magnus, and Dan Johansson (2010), "Gazelles as Job Creators-A Survey and Interpretation of the Evidence." Small Business Economics 35(2), 227-244.

Henrekson, Magnus, and Mikael Stenkula (2010), "Entrepreneurship and Public Policy." In Zoltan J. Acs and David B. Audretsch, eds., Handbook of Entrepreneurship Research: An Interdisciplinary Survey and Introduction (pp. 595-637). New York: Springer.

Henrekson, Magnus, and Tino Sanandaji (2011), "Entrepreneurship and the Theory of Taxation." Small Business Economics 37(2), 167-185.

Henrekson, Magnus, and Tino Sanandaji (2014), "Small Business Activity Does not Measure Entrepreneurship." Proceedings of the National Academy of Sciences of the United States of America (PNAS) 111(5), 1760-1765. 
Ho, Yuen-Ping, and Poh-Kam Wong (2007), "Financing, Regulatory Costs and Entrepreneurial Propensity." Small Business Economics 28(2-3), 187-204.

Holtz-Eakin, Douglas (2000), "Public Policy toward Entrepreneurship." Small Business Economics 15(4), 283-291.

Johannisson, Bengt (1984), "A Cultural Perspective on Small Business-Local Business Climate." International Small Business Journal 2(2), 32-43.

Johannisson, Bengt, and Caroline Wigren (2006), "The Dynamics of Community Identity Making in an Industrial District: The Spirit of Gnosjö Revisited." In Chris Steyaert and Daniel Hjort, eds., Entrepreneurship as Social Change. Cheltenham, UK and Northampton, MA: Edward Elgar.

Johansson, Dan (2010), "The Theory of the Experimentally Organized Economy and Competence Blocs: An Introduction." Journal of Evolutionary Economics 20(2), 185-201.

Jorgenson, Dale W., and Ralph Landau, eds. (1993), Tax Reform and the Cost of Capital. An International Comparison. Washington, D.C.: Brookings.

Kim, Philip H., and Howard E. Aldrich (2005), "Social Capital and Entrepreneurship." Foundations and Trends in Entrepreneurship 1(2), 55-104.

Kirzner, Israel M. (1973), Competition and Entrepreneurship. Chicago: University of Chicago Press.

Klepper, Steven (2001), "Employee Startups in High-Tech Industries." Industrial and Corporate Change 10(3), 639-674.

Klepper, Steven (2002), "The Capabilities of New Firms and the Evolution of the U.S. Automobile Industry." Industrial and Corporate Change 11(4), 645-666.

Klepper, Steven (2011), "Nano-Economics, Spinoffs and the Wealth of Regions." Small Business Economics 37(1), 141-154.

Klepper, Steven, (2010), "The Origin and Growth of Industry Clusters: The Making of Silicon Valley and Detroit." Journal of Urban Economics 67(1), 15-32.

Klepper, Steven, and Sally Sleeper (2005), "Entry by Spinoffs." Management Science 51(8), 1291-1306.

Klyver, Kim, Kevin Hindle and Thomas Schøtt (2007), "Who Will Be an Entrepreneur? How Cultural Mechanisms and Social Network Structure Together Influence Entrepreneurial Participation." Frontiers of Entrepreneurship Research 27(7), 305-320.

Kolko, Jed, David Neumark and Maricol Cuellar Mejia (2013), "What do Business Climate Indexes Teach us about State Policy and Economic Growth?" Journal of Regional Science 53(2), 220-255.

Krugman, Paul R. (1994), “Competitiveness: A Dangerous Obsession.” Foreign Affairs 73(2), 28-44.

Larsson, Gerhard (2006), Spatial Planning Systems in Europe: An Overview. Amsterdam: IOS Press. 
Larsson, Johan P (2014), "The Neighborhood or the Region? Reassessing the Density-Wage Relationship Using Geo-Coded Data." Annals of Regional Science, forthcoming (http://link.springer.com/article/10.1007/s00168-014-0590-8.).

Lazerson, Marco H., and Gianni Lorenzoni (1999), "The Firms That Feed Industrial Districts: A Return to the Italian Source." Industrial and Corporate Change 8(2), 235-266.

Lerner, Josh (2009), Boulevard of Broken Dreams: Why Public Efforts to Boost Entrepreneurship and Venture Capital Have Failed-and What to Do about It. Princeton, NJ: Princeton University Press.

Lucas, Robert E. (1978), "On the Size Distribution of Business Firms." Bell Journal of Economics 9(2), 508523.

Lundström, Anders, and Lois Stevenson (2002), On the Road to Entrepreneurship Policy. Volume 1 of the Entrepreneurship Policy for the Future Series. Örebro: FSF.

Malone, Michael S. (1985), The Big Score: The Billion Dollar Story of Silicon Valley. Garden City, NJ: Doubleday.

Markusen, James R. (1995), "The Boundaries of Multinational Enterprises and the Theory of International Trade." Journal of Economic Perspectives 9(1), 169-189.

Marshall, Alfred (1890), Principles of Economics. London: Macmillan.

Martin, John, and Stefano Scarpetta (2012),"Setting It Right: Employment Protection, Labour Reallocation and Productivity." De Economist 160(2), 89-116.

Mata, José, Pedro Portugal and Paulo Guimarães (1995), "The Survival of New Plants: Start-Up Conditions and Post-Entry Survival." International Journal of Industrial Organization, 13, 459-481.

Minniti, Maria (2005), "Entrepreneurship and Network Externalities." Journal of Economic Behavior and Organization 57(1), 1-27.

Moretti, Enrico (2012), The New Geography of Jobs. New York: Houghton Mifflin Harcourt.

Moretti, Enrico, and Per Thulin (2013), "Local Multipliers and Human Capital in the United States and Sweden." Industrial and Corporate Change 22(1), 339-362.

Murphy, Kevin M, Andrei Shleifer and Robert W. Vishny (1991), "The Allocation of Talent: Implications for Growth." Quarterly Journal of Economics 106(2), 503-530.

Myrdal, Gunnar (1957), Economic Theory and Underdeveloped Regions. London: University Paperbacks, Methuen.

Nanda, Ramana, and Jesper B. Sorensen (2010), "Workplace Peers and Entrepreneurship." Management Science 56(7), 1116-1126. 
Nathan, Max, and Henry Overman (2013), "Agglomeration, Clusters, and Industrial Policy." Oxford Review of Economic Policy 29(2), 383-404.

Nicoletti , Giuseppe, and Stefano Scarpetta (2003), "Regulation, Productivity and Growth: OECD Evidence." Economic Policy 18(36), 9-72.

North, Douglass C. (1990), Institutions, Institutional Change and Economic Performance, Cambridge: Cambridge University Press.

OECD (1997), The OECD Report of Regulatory Reform. Paris: OECD.

OECD (2003), The Sources of Economic Growth in the OECD Countries. Paris: OECD.

Papke, Leslie E. (1991), "Interstate Tax Differentials and New Firm Location." Journal of Public Economics 45(1), 47-68.

Pflüger, Michael, and Jens Südekum (2008), “A Synthesis of Footloose-Entrepreneur New Economic Geography Models - When is Agglomeration Smooth and Easily Reversible?" Journal of Economic Geography 8(1), 39-54.

Piore, Michael J., and Charles F. Sabel (1984), The Second Industrial Divide: Possibilities for Prosperity. New York: Basic Books.

Putnam, Robert D. (1993), Making Democracy Work: Civic Traditions in Modern Italy. Princeton, NJ: Princeton University Press.

Rodrik, Dani, Arvind Subramanian and Francesco Trebbi (2004), "Institutions Rule: The Primacy of Institutions over Geography and Integration in Economic Development." Journal of Economic Growth 9(2), 131-165.

Rosen, Harvey S. (2005), "Entrepreneurship and Taxation: Empirical Evidence." In Vesa Kanniainen and Christian Keuschnigg, eds., Venture Capital, Entrepreneurship and Public Policy. Cambridge, MA: MIT Press.

Rosenberg, Nathan, and Luther E. Birdzell (1986), How the West Grew Rich: The Economic Transformation of the Industrial World. New York: Basic Books.

Saez, Emmanuel (2010), “Do Tax Filers Bunch at Kink Points? Evidence, Elasticity Estimation, and Salience Effects." American Economic Journal: Economic Policy 2(3), 180-212.

Saxenian, AnnaLee (1994), Regional Advantage: Culture and Competition in Silicon Valley and Route 128. Cambridge, MA: Harvard University Press.

Schivardi, Fabiano, and Roberto Torrini (2008), "Identifying the Effects of Firing Restrictions through SizeContingent Differences in Regulation." Labour Economics 15(3), 482-511. 
Schneider, Cédric, and Reinhilde Veugelers (2010), "On Young Highly Innovative Companies: Why They Matter and How (not) to Policy Support Them." Industrial and Corporate Change 19(4), 969-1007.

Schuetze, Herbert J., and Donald Bruce (2004), "Tax Policy and Entrepreneurship." Swedish Economic Policy Review 11(2), 233-265.

Schultz, Theodore W. (1979), Concepts of Entrepreneurship and Agricultural Research. Kaldor Memorial Lecture, lowa State University, October.

Schumpeter, Joseph A. (1934), The Theory of Economic Development. Cambridge, MA: Harvard University Press.

Shane, Scott (2003), A General Theory of Entrepreneurship: The Individual-Opportunity Nexus. Cheltenham, UK and Northampton, MA: Edward Elgar.

Shane, Scott (2008), The Illusions of Entrepreneurship: The Costly Myths That Entrepreneurs, Investors, and Policy Makers Live by. New Haven, CT: Yale University Press

Sillamaa, Mary Anne, and Michael Veall (2001), "The Effect of Marginal Tax Rates on Taxable Income: A Panel Study of the 1988 Tax Flattening in Canada." Journal of Public Economics 80(3), 341-356.

Sinn, Hans-Werner (1996), "Social Insurance, Incentives and Risk Taking." International Tax and Public Finance 3(3), 259-280.

Skedinger, Per (2010), Employment Protection Legislation: Evolution, Effects, Winners and Losers. Cheltenham, UK and Northampton, MA: Edward Elgar.

Small Business Administration (2007), 2007 Survey of Business Owners. Available at: http://www.census.gov/econ/sbo/.

Smith, Vernon (2003), "Constructivist and Ecological Rationality in Economics." American Economic Review 93(3), 465-490.

Sombart, Werner (1911),:Die Juden und das Wirtschaftsleben. Leipzig: Duncker. Translated into English in 2001 as The Jews and Modern Capitalism. Kitchener: Batoche Books.

Sorenson, Olav, and Pino G. Audia (2000), "The Social Structure of Entrepreneurial Activity: Geographic Concentration of Footwear Production in the United States, 1940-1989." American Journal of Sociology 106(2), 424-462.

Stangler, Dane (2010), "High-Growth Firms and the Future of the American Economy." Kaufman Foundation Research Series: Firm Formation and Economic Growth. Kansas City, MO: Ewing Marion Kauffman Foundation.

Tannenwald, Robert (1997), "State Regulatory Policy and Economic Development." New England Economic Review, March/April, 83-107. 
van Stel, André, David Storey and A. Roy Thurik (2007), "The Effect of Business Regulations on Nascent and Young Business Entrepreneurship." Small Business Economics 28(2-3), 171-186.

Weber, Max (1930), The Protestant Ethic and the Spirit of Capitalism. London: Allen and Unwin.

Wennekers, Sander, and A. Roy Thurik (1999), "Linking Entrepreneurship and Economic Growth." Small Business Economics 13(1), 27-56.

Westlund, Hans, Johan P. Larsson and Amy Rader Olsson (2014), "Startups and Local Entrepreneurial Social Capital in the Municipalities of Sweden." Regional Studies, forthcoming (http://dx.doi.org/10.1080/00343404.2013.865836).

Williamson, Oliver E. (2000), "The New Institutional Economics - Taking Stock and Looking Ahead." Journal of Economic Literature 38(3), 595-661. 